PAWEŁ DETTLOFF

Kraków, Instytut Sztuki PAN

\title{
„Obraz srebrny” z kościoła kanoników regularnych w Mstowie
}

$\mathrm{K}$ ościół kanoników regularnych pw. Wniebowzięcia NMP w Mstowie koło Częstochowy (aktualnie w granicach administracyjnych Wancerzowa) posiada średsię w niej, w ołtarzu bocznym prawego ramienia transeptu obraz - znany dziś jako Matka Boska Mstowska - to graficzna reprodukcja słynnego wizerunku Matki Boskiej Częstochowskiej. Według tradycji odbitkę zakupiono na Jasnej Górze jako dewocyjną pamiątkę z pielgrzymki. Wkrótce obrazek zasłynął cudami, co sprawiło, że z rąk prywatnych szybko trafił do kościoła jako obraz sakralny o szczególnym znaczeniu².

\section{Stan badań}

W ekspozycji cudownego wizerunku Matki Boskiej Mstowskiej podstawową rolę odgrywa nałożona na obrazek srebrna blacha, która zasłania go niemal w całości, z wyjątkiem twarzy przedstawionych postaci (il. 1). Należy podkreślić, że dzieło to jest praktycznie nieznane. W Katalogu zabytków sztuki powiatu częstochowskiego czas wykonania „późnobarokowej sukienki” określono na początek XVIII w. ${ }^{3}$ Ks. Kazimierz Łatak łączył fundację tej ozdoby z osobą prepozyta Jana Zakrzowskiego (1705-1746) ${ }^{4}$. Jak dotąd nie przeprowadzono dokładnych badań dzieła, nie podjęto prób uściślenia czasu i okoliczności jego powstania ani nie dokonano szczegółowej analizy form artystycznych. Jedną z poważnych przeszkód w podjęciu tych zadań stanowi utrudniony dostęp do zabytku. Jest on umieszczony w nastawie ołtarzowej, co wobec niewielkich rozmiarów samego dzieła czyni je słabo widocznym, zwłaszcza w szczegółach. Znamienne jest, że w katalogu zabytków Małopolski wydanym ostatnio w serii Dehio-Handbuch der Kunstdenkmäler obiekt został pominięty lub niezauważony ${ }^{5}$.

\footnotetext{
${ }^{1}$ Paweł DETTLOFF, „Kościół kanoników regularnych laterańskich w Mstowie”, Kwartalnik Architektury i Urbanistyki, 43:1998, z. 4, s. 291-305; id., „Architektura kościoła Kanoników Regularnych Laterańskich w Mstowie”, [w:] Mstów. Miasto, klasztor i parafia na przestrzeni wieków, red. Kazimierz ŁATAK CRL, Łomianki 2013, s. 245-266.

${ }^{2}$ Kazimierz ŁATAK CRL, Sanktuarium Matki Bożej Mstowskiej, Ełk 2000, s. 43-54.

${ }^{3}$ Katalog zabytków sztuki w Polsce, t. 6: Województwo katowickie, z. 4: Dawny powiat częstochowski, red. Izabella REJDUCH-SAMKOWA i Jan SAMEK, oprac. Przemysław MALISZEWSKI i Adam MAŁKIEWICZ oraz Izabella REJDUCH-SAMKOWA i Jan SAMEK, Warszawa 1979, s. 13.

${ }^{4}$ ŁATAK, op. cit., s. 55, 61; id., „Katalog rządców prepozytury mstowskiej”, [w:] Mstów..., s. 478.

${ }^{5}$ Zabytki sztuki w Polsce. Małopolska, red. Sławomir BRZEZICKI i Joanna WOLAŃSKA, Warszawa 2016, s. 925.
} 


\section{Historia}

Słynąca łaskami graficzna reprodukcja obrazu Matki Boskiej Częstochowskiej trafiła do kościoła kanoników regularnych w Mstowie w roku 1647 i już wkrótce rosnąca cześć okazywana przez wiernych wizerunkowi sprawiła, że wokół pojawiać zaczęły się wota i drogocenne ozdoby. Mówią o tym wyraźnie teksty z epoki: Historya [...] o Obrazie Najświętszej Maryi Panny w kościele mstowskim ks. Szymona Paszyńskiego z 1660 r., który wspomina o „srebrach i wotach” składanych przy obrazie przez „ludzi różnego stanu”, oraz Morze łaski Bożej Piotra Hiacynta Pruszcza z roku $1662^{7}$, gdzie znalazły się podobne relacje. Pruszcz akcentuje przy tym rolę pierwszych właścicieli - małżeństwa Widawskich, a zwłaszcza Baltazara Wężyka Widawskiego, który wyposażył obraz w stosowne ozdoby i wota. Widawscy sprawić mieli m.in. srebrną „oprawę” obrazu oraz dwie lampy (lichtarze), a także ,wotum swoje na łokieć”, czyli przedstawienie wotywne z postacią fundatorów. Szczególnie interesujący, ale niestety nieprecyzyjny jest zapis o „oprawie” obrazu, czyli jego ramie lub może nawet pierwszej aplikacji - sukience ${ }^{8}$. W Morzu łaski Bożej podkreślone zostało również zaangażowanie okolicznej szlachty składającej inne dary9

Kolejny przekaz źródłowy o dekoracjach obrazu zamieszczony jest w aktach wizytacji biskupiej w Mstowie z roku $1683^{10}$. Znajduje się tam spis cenniejszych przedmiotów, w tym precjozów wykonanych z drogich materiałów. Niestety, choć ujmuje on bardzo wiele obiektów, jest chaotyczny, a miejscami niejasny. W protokole wizytacji znalazł się także zagadkowy zapis: „Ołtarzyk około obrazu srebr In toto Ramy hebanowe w srebro oprawne"11. Chodzić tu może o małe retabulum lub obramienie obrazu w kształcie niewielkiego ołtarzyka. Nie ma pewności, czy stało ono osobno, czy też umieszczone było w większej nastawie ołtarzowej - niewykluczone, że w tej samej, w której znajdowało się przedstawienie Matki Boskiej Różańcowej. „Obrazem” owym był bez wątpienia ozdobiony srebrną aplikacją wizerunek Matki Boskiej Mstowskiej, natomiast wspomniana w zapisie hebanowo-srebrna rama pod względem użytych materiałów i charakterystycznego zestawienia kolorystycznego nawiązywała z pewnością do nastawy ołtarzowej w kaplicy cudownego obrazu Matki Boskiej na Jasnej Górze, ufundowanej przez Jerzego Ossolińskiego $^{12}$. Podkreślać to mogło związek czczonego w Mstowie wizerunku z jego jasnogórskim pierwowzorem. Należy żałować, że hebanowa rama ze srebrnymi aplikacjami nie zachowała się do naszych czasów. Zrezygnowano z niej najpóźniej przed połową XVIII w., kiedy to wykonano nową, bardziej aktualną stylowo, rokokową - obecnie istniejącą ramę obrazu. Srebrne aplikacje hebanowej ramy mogły być już wcześniej wykorzystane do sfinansowania nowych inwestycji artystycznych w kościele. Niewykluczone także, że przetopione ozdoby ramy posłużyły do wykonania obecnej sukienki obrazu Matki Boskiej Mstowskiej, o czym będzie jeszcze mowa.

\footnotetext{
${ }^{6}$ ks. Szymon PASZYŃSKI, Historya [...] o Obrazie Najświętszej Maryi Panny w kościele mstowskim, ok. 1660. Cyt. za: ŁATAK, Sanktuarium..., s. 80.

${ }^{7}$ Piotr Hiacynt PRUSZCZ, Morze łaski Bożej, Kraków 1662, s. 37-38.

${ }^{8}$ Ibid.

${ }^{9}$ Ibid., s. 37-38.

${ }^{10}$ Archiwum Diecezjalne we Włocławku (dalej ADW), sygn. AAG: Akta wizytacji biskupich archidiecezji gnieźnieńskiej (kościoła kanoników regularnych w Mstowie), Vis. 8: Akta wizytacji kościoła z 1683 r., s. 281-282.

${ }^{11}$ Ibid., s. 282.

${ }^{12} \mathrm{Na}$ temat tego ołtarza Jan GOLONKA OSPE, Oltarz Jasnogórskiej Bogurodzicy. Treści ideowe i artystyczne kaplicy i retabulum, Częstochowa - Jasna Góra 1996, s. 57-66.
} 


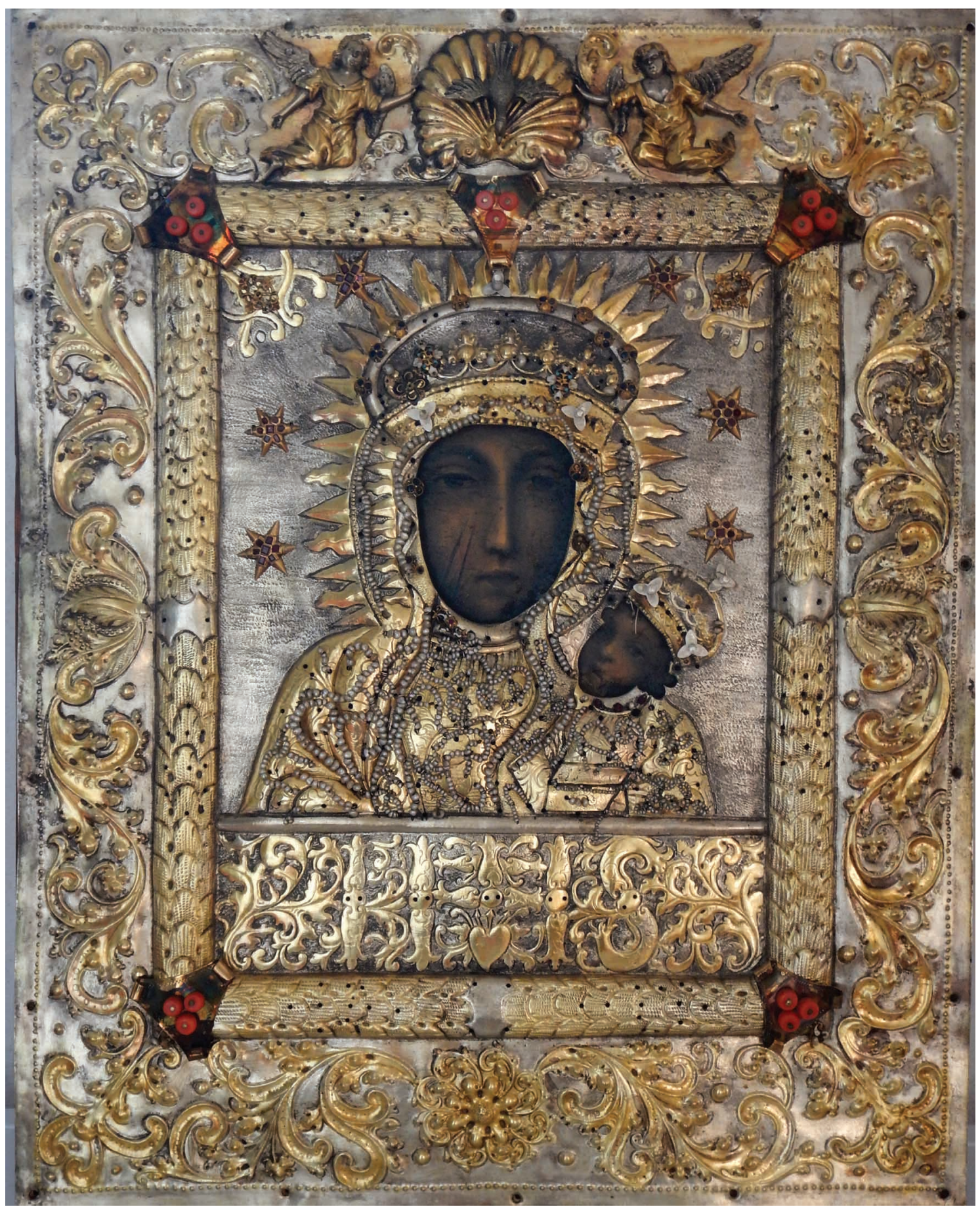

1. Obraz Matki Boskiej Mstowskiej w srebrnej sukience. Stan z 2018 r. Fot. P. Dettloff 


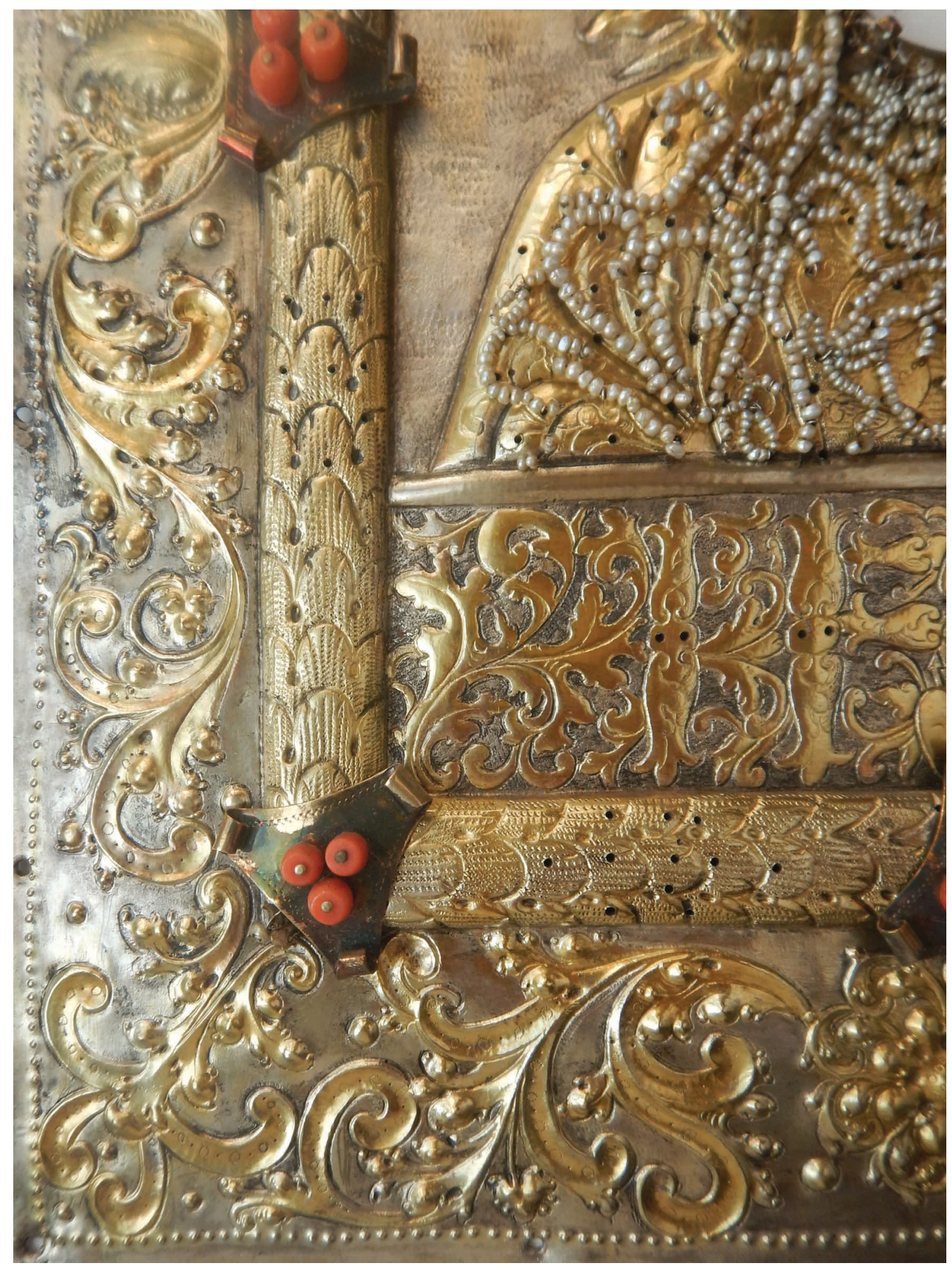

2. Fragment srebrnej sukienki. Fot. P. Dettloff 


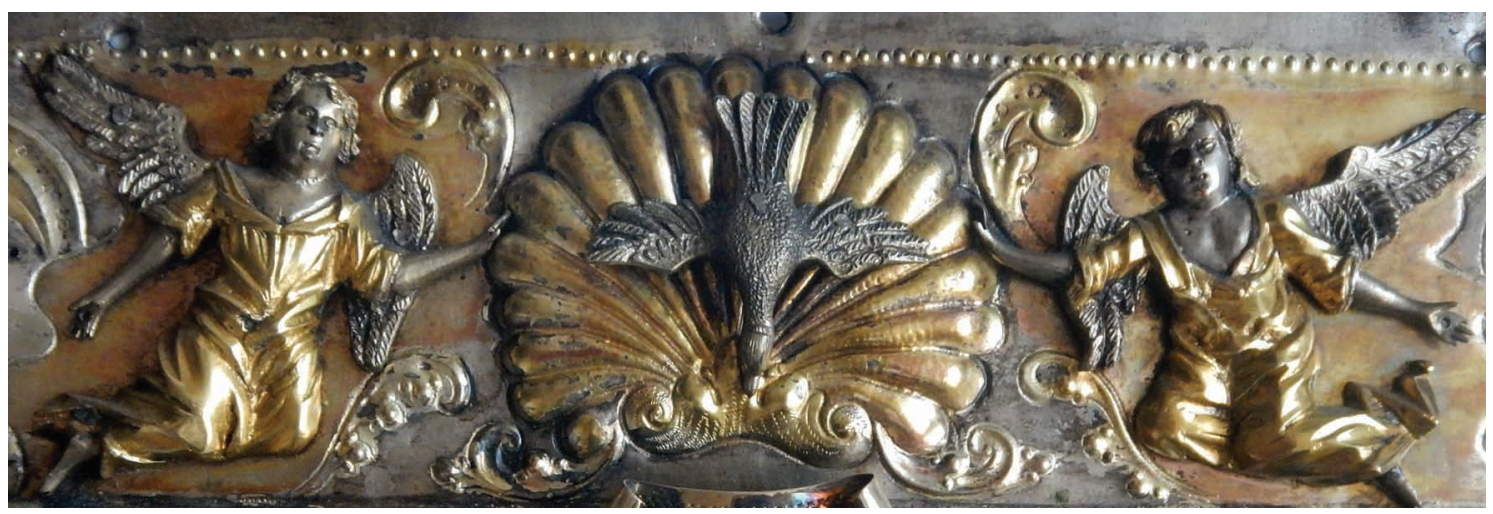

3. Fragment srebrnej sukienki - przedstawienie Ducha Świętego. Fot. P. Dettloff

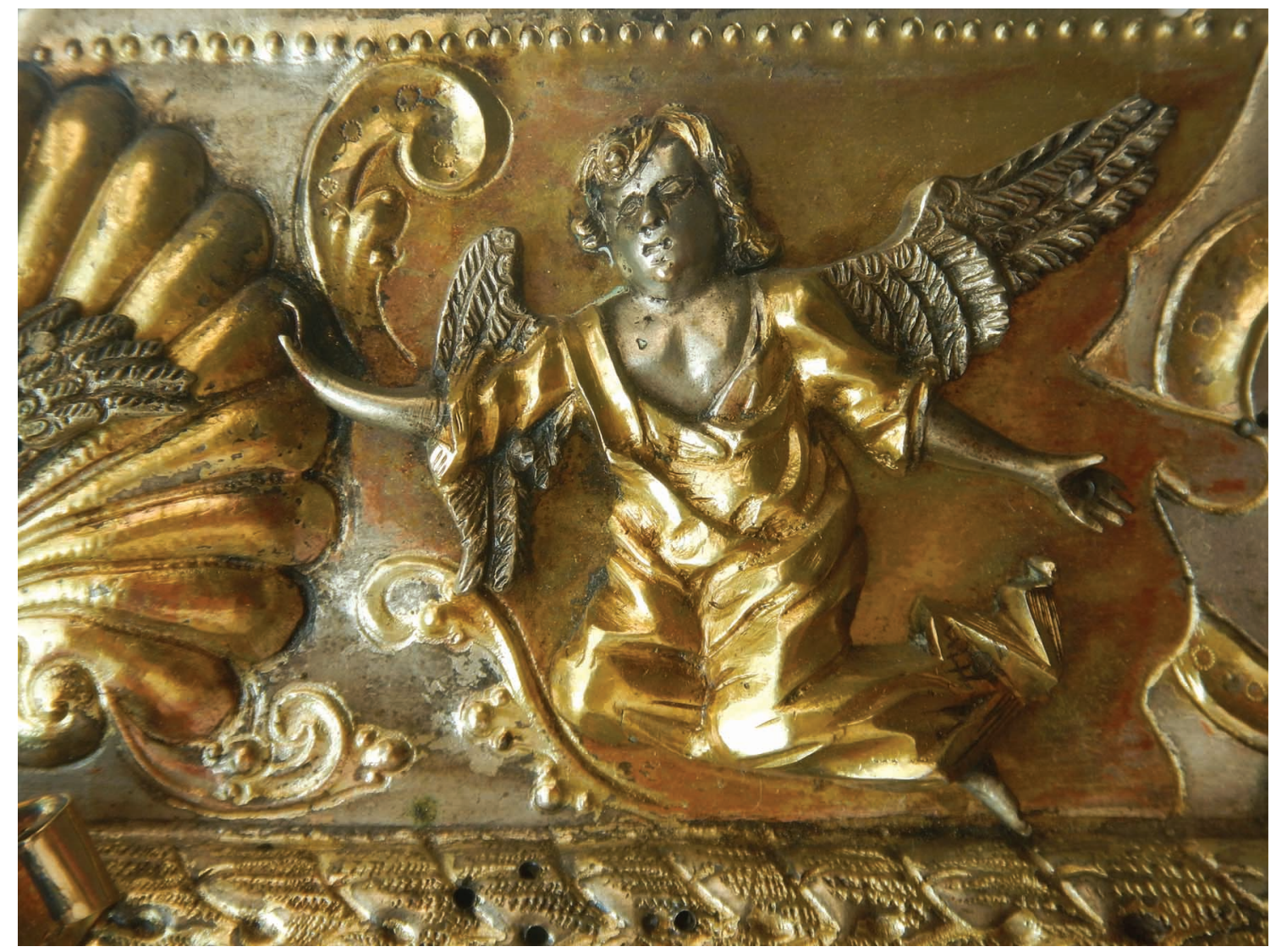

4. Fragment srebrnej sukienki - aniot. Fot. P. Dettloff 
Bardzo cennym źródłem archiwalnym na temat niektórych przedsięwzięć w kościele kanoników regularnych w Mstowie jest księga przychodów i wydatków zakrystii z lat 1703-1734 ${ }^{13}$. W umieszczonym w niej spisie argentariów kościelnych z 1704 r. znalazł się następujący zapis: „Do obrazu cudownego ołtarzyk w którym obraz srebrny”14. Owym „obrazem srebrnym” była zapewne sukienka, która w rzeczywistości jest odtworzonym na repusowanej blasze niemal pełnym przedstawieniem Matki Boskiej Mstowskiej. Z dalszej części opisu dowiadujemy się, że nad obrazem znajdowała się „tabliczka wielka srebrna", a w jego otoczeniu umieszczone były jeszcze inne liczne wota, w tym przedstawienia dzieci, serc, wózków itp. ${ }^{15} \mathrm{Z}$ księgi zakrystyjnej dowiadujemy się również, że wota zawieszano na specjalnie wykonanej parze kolumn, stawianej przed obrazem ${ }^{16}$. Do tego samego celu służyła zapewne także ,laska hebanowa przed obraz”, wykonana przez stolarza w 1726 r. $^{17}$

Aplikacje ze srebra na obrazie Matki Boskiej Mstowskiej odnotowano także w protokole wizytacji z roku $1747^{18}$. Wymieniony w nim został m.in. ołtarz „Habens Imaginem Częstochowiensem B. Matris Dei Gratiosum Veste Argentea adornatum”, a zatem taki, w którym obraz z wizerunkiem Matki Boskiej Częstochowskiej ozdobiony jest srebrną szatą. Tę ostatnią identyfikować należy z pewnością z obecnie istniejącą srebrną sukienką, wykonaną jednak bez wątpienia znacznie wcześniej.

\section{Dzieło zlotnicze - analiza formy artystycznej}

Metalowa aplikacja wizerunku Matki Boskiej Mstowskiej, czyli tak zwana sukienka (il. 1) ma kształt stojącego prostokąta, którego rozmiary $\left(48 \times 38 \mathrm{~cm}^{19}\right)$ przekraczają wielkość samego obrazu $(25 \times 30 \mathrm{~cm})$, zakrywając całą jego powierzchnię z wyjątkiem twarzy Maryi i Dzieciątka Jezus. Sukienkę sporządzono ze srebrnej i częściowo złoconej blachy repusowanej, miejscami rytowanej. Elementy figuralne - w górnej części niemal pełnoplastyczne i wykonane w technice odlewu - przymocowane zostały śrubami do blachy, tworząc z nią integralną całość formalną (il. 1, 3). Kompozycja okrywy składa się z dwóch zasadniczych części: środkowej, obejmującej wizerunek Matki Boskiej wraz z gładkim tłem, oraz okalającej szerokiej bordiury. U dołu części środkowej znajduje się wydzielony pas z chrystogramem (IHS), którego litery utworzone zostały z ornamentalnych form w typie spłaszczonego akantu, z motywem serca w dole litery H (il. 6). Pozostałą (górną) strefę części środkowej wypełnia gładka powierzchnia z pojedynczymi aplikacjami oraz plastycznym przedstawieniem szat obu ukoronowanych postaci - Matki Boskiej i Dzieciątka. Głowę Maryi okala promienista aureola złożona z alternujących promyków prostych i płomienistych (il. 1, 6). Szaty Matki Boskiej i Dzieciątka pokryte są skromną i płaską dekoracją w typie stylizowanych listków (il. 2). Niektóre jej elementy zaznaczone są wykłuwanymi i wybijanymi (puncowanymi) kropkami. W górnych naroż-

\footnotetext{
${ }^{13}$ Archiwum Archidiecezji Częstochowskiej, sygn. KP 207: Księga wydatków zakrystii kościoła kanoników regularnych w Mstowie - Regestr dochodów i wydatków i co przybyło 1703.X.-1734.3.X.

${ }^{14}$ Ibid., s. 83.

${ }^{15}$ Ibid.

16 Ibid., s. 89.

17 Ibid., s. 85 .

${ }^{18}$ ADW, sygn. AAG, Vis. 17: Akta wizytacji kościoła z 1747 r., s. 26-28.

${ }^{19}$ Rozmiary boków nieznacznie różnią się między sobą. Wysokość wynosi 47,5 cm z prawej i 48,5 z lewej strony; podobnie szerokość: u góry $38 \mathrm{~cm}$, u dołu $38,5 \mathrm{~cm}$.
} 


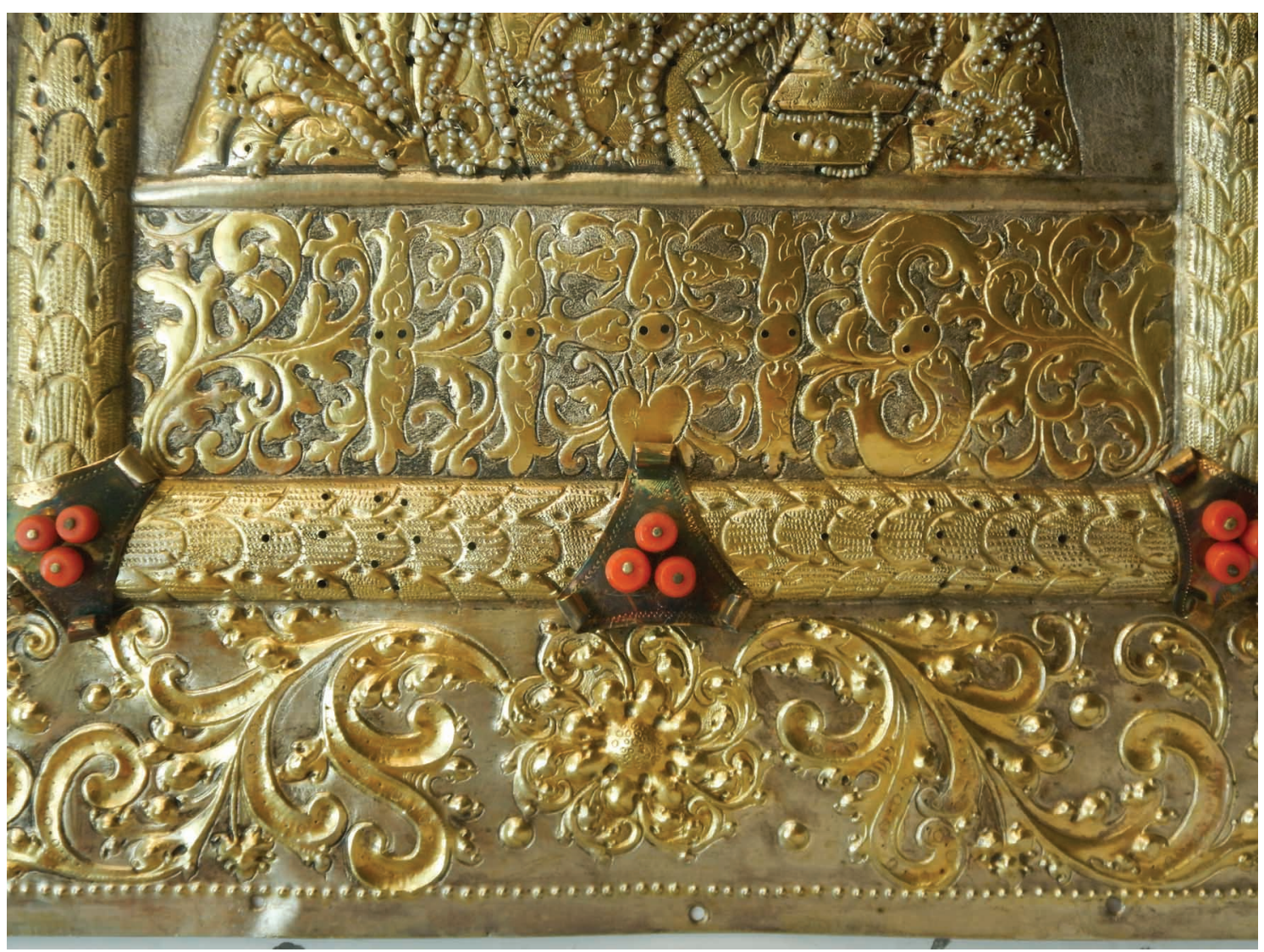

5. Fragment srebrnej sukienki - chrystogram IHS w dolnej części. Fot. P. Dettloff

nikach tła umieszczone zostały kompozycje złożone z czterech wyginających się esowato i przecinających płaskich taśm. Część środkowa obwiedziona jest ramą w formie wypukłego pasa $\mathrm{z}$ motywem stylizowanych liści lauru. Bordiurę zdobi wydobywająca się z płaskiego tła, wypukła wić ornamentalna z wplecionymi wolutami przechodzącymi w motywy akantowych listków. U jej dołu pośrodku znajduje się kompozycja w formie wirującej rozety, którą tworzą stylizowane liście akantu (il. 1-2). W górnej części natomiast, ponad laurową ramą „obrazka” widnieje grupa figuralna złożona z pary klęczących aniołów podtrzymujących odwróconą wierzchem muszlę, na której umieszczono wyobrażenie Ducha Świętego pod postacią gołębicy (il. 4). Pozostałe elementy dodane zostały do srebrnej blachy wtórnie. Są to w większości XVII-wieczne sztuczki, aplikowane do wizerunku w celu wzbogacenia i uświetnienia go drogocenną biżuterią.

Dokładne datowanie i ustalenie proweniencji omawianego zabytku utrudnia brak jakichkolwiek cech złotniczych. Na obiekcie nie ma bowiem ani cech miejskich - probierczych, ani imiennych punc rzemieślników. Znaki te pozwalają z reguły na dość precyzyjne określenie czasu i miejsca powstania dzieła, a niekiedy umożliwiają nawet identyfikację jego twórcy $^{20}$. Ich nieobecność na sukience obrazu Matki Boskiej Mstowskiej nie czyni jednak z tego obiektu przypadku odosobnionego ${ }^{21}$. Aplikacje takie dość często wykonywane były

\footnotetext{
${ }^{20}$ Michał GRADOWSKI, Znaki na srebrze. Znaki miejskie i państwowe na terenie Polski w obecnych jej granicach, Warszawa 1994, s. 17-19, 21-29, 59-270.

${ }^{21}$ Szereg przykładów podaje Michał WOŹNIAK, Złotnictwo sakralne Prus Królewskich. Studium typologiczno-morfologiczne, Toruń 2012, s. 228, 231, 234.
} 
ze stopu srebra o zbyt niskiej próbie, by mogły być cechowane, lub też z metali nieszlachetnych, np. blachy miedzianej złoconej bądź srebrzonej ${ }^{22}$. Z kolei obowiązek znakowania wyrobu z metalu szlachetnego cechą imienną i miejską - probierczą w czasach staropolskich nie zawsze był przestrzegany. Zwłaszcza w Małopolsce oraz na Mazowszu i dalej na wschód znaki miejskie pojawiały się rzadko ${ }^{23}$. Podobny problem dotyczył także punc imiennych rzemieślników ${ }^{24}$. Dopiero od XVIII stulecia znaki takie wraz z oznaczeniem prób i herbu miasta stawały się powszechne ${ }^{25}$.

Co ciekawe, użycie srebra o nieznanej próbie ${ }^{26}$, a zwłaszcza brak cech złotniczych mogłyby w pewnym stopniu okazać się pomocne w badaniach omawianego zabytku. Okoliczności te pozwalają bowiem na wykluczenie wykonania sukienki w ośrodku, w którym bezwzględnie przestrzegano zasady znakowania wyrobów puncami miejskimi i imiennymi. W tym kontekście na szczególne zainteresowanie zasługuje Częstochowa, a więc ośrodek złotniczy, który także z racji położenia geograficznego należałoby w pierwszej kolejności brać pod uwagę w próbach ustalenia proweniencji zabytku. Do XVIII stulecia najprawdopodobniej nie wprowadzono tu regulacji dotyczących norm oznakowania wyrobów. Ośrodek ten specjalizował się głównie w przeznaczonych dla pątników plakietach wotywnych wykonywanych z metalu lub srebra niskiej próby ${ }^{27}$. Omawiane dzieło sztuki prezentuje wyższą klasę artystyczną niż wspomniane seryjne wyroby dla pielgrzymów. Wiadomo jednak, że złotnicy częstochowscy wykonywali także bardziej ambitne prace.

W badaniach nad proweniencją obiektu należy wziąć pod uwagę również fakt, że kościoły i klasztory regionu częstochowskiego zaopatrywane były w dzieła także w bardziej odległych ośrodkach sztuki złotniczej, przede wszystkim w Krakowie i Toruniu. Na przykład w stosunkowo niedalekich od Mstowa Gidlach w XVII i XVIII w. korzystano z usług krakowskich złotników; niekiedy też sprowadzano obiekty z Torunia ${ }^{28}$. W Mstowie w 1754 r. sprzedano część kosztowności i wotów krakowskiemu złotnikowi Janowi Piotrowskiemu, aby z uzyskanych pieniędzy pokryć wydatki na prace w kościele kanoników regularnych ${ }^{29}$. Fakt ten wyraźnie wskazuje na utrzymywanie związków klasztoru z Krakowem, choć oczywiście nie przesądza o miejscu powstania omawianego zabytku.

Srebrne lub blaszane aplikacje na obrazach sakralnych, w Polsce zwane sukienkami, zachowały się dość licznie. Większość z nich pochodzi z około 1700 r. i z pierwszej połowy XVIII stulecia ${ }^{30}$, starsze datowane są przeważnie na 4. ćwierć XVII w. Dokładnie przebadane naukowo zostały tylko niektóre $\mathrm{z}$ nich, pozostałe nie są opracowane lub wzmiankowane bywają jedynie marginalnie w katalogach zabytków. Pomimo zaintereso-

\footnotetext{
22 WOŹNIAK, op. cit., s. 228, przyp. 30.

${ }^{23}$ GRADOWSKI, op. cit., s. 26-27.

${ }^{24} \mathrm{~W}$ Krakowie niejednokrotnie brak takich cech na ewidentnie miejscowych wyrobach. Por. GRADOWSKI, op. cit., s. 98.

${ }^{25}$ GRADOWSKI, op. cit., s. 98.

${ }^{26}$ Mstowska sukienka nie była badana pod kątem rzeczywistego składu materiału. Trudno też na podstawie samego wyglądu określić jego próbę.

${ }^{27}$ GRADOWSKI, op. cit., s. 184-185. Por. Jan SAMEK, Izabella REJDUCH-SAMKOWA, „Czy złotnictwo polskie XVII wieku ma własne oblicze?”, [w:] Sztuka XVII wieku w Polsce. Materiały Sesji Stowarzyszenia Historyków Sztuki, Kraków, grudzień 1993, Warszawa 1994, s. 255.

28 Anna DETTLOFF, Paweł DETTLOFF, Domus Aurea. Architektura i sztuka dominikańskiego sanktuarium Matki Bożej w Gidlach, Warszawa 2016, s. 130-131, 154-155, 231.

${ }^{29}$ ŁATAK, Sanktuarium..., s. 55 i przyp. 94; Janusz ZBUDNIEWEK OSPE, „Archiwalia do dziejów klasztoru mstowskiego przechowywane w Archiwum Klasztoru Paulinów na Jasnej Górze”, [w:] Mstów..., s. 378.

${ }^{30}$ WOŹNIAK, op. cit., s. 235.
} 
wania naukowców powszechnym w Rzeczypospolitej zjawiskiem fundowania srebrnych aplikacji obrazów sakralnych jak dotąd nie podjęto kompleksowych i metodycznych badań tego rodzaju zabytków w skali całego kraju. Brak ich naukowego korpusu utrudnia wyciągnięcie wniosków natury ogólnej dotyczących występowania określonych typów i dekoracji w poszczególnych regionach dawnej Rzeczypospolitej. Najsłabiej rozpoznane są zaś właśnie Małopolska i Śląsk, czyli tereny mogące mieć potencjalnie największe znaczenie dla omawianego dzieła.

Sukienka obrazu Matki Boskiej Mstowskiej prezentuje, według klasyfikacji zaproponowanej przez Mariusz Karpowicza ${ }^{31}$, typ stosunkowo rzadki. W tej grupie blachy wykraczają poza „sukienki”, przeważnie ograniczające się wyłącznie do „szat” postaci. Aplikacje pokrywają tym samym cały obraz wraz z tłem, pozostawiając jedynie otwory na twarze. Ten typ budzić może skojarzenia z tradycją bizantyńską i zwyczajem niemal całkowitego osłaniania ikon blaszanymi lub srebrnymi okładami w kościołach wschodnich. Podobieństwo to jest jednak przypadkowe. Zwyczaj nakładania metalowych aplikacji na przedstawienia plastyczne znany był w Europie łacińskiej od średniowiecza, choć kojarzono go w czasach nowożytnych z obrządkiem wschodnim ${ }^{32}$. Przyczynami, dla których zdecydowano się na zastosowanie niemal pełnego okrycia mstowskiego obrazka, są jego niewielkie rozmiary i technika wykonania. Dla tak małego wizerunku wykonanie aplikacji samych szat byłoby zapewne trudniejsze. Kłopotliwe mogłoby okazać się także umocowanie pojedynczych elementów na papierze - materiale nietrwałym i podatnym na uszkodzenia mechaniczne. Bardziej bezpiecznym i zarazem efektownym rozwiązaniem było pokrycie całości jednolitą blachą, obejmującą postacie i tło.

Wobec nieobecności znaków złotniczych na zabytku oraz braku precyzyjnych, odnoszących się do jego wykonania danych archiwalnych, próbę określenia czasu, miejsca i kręgu, w jakim omawiane dzieło powstało, podjąć można jedynie na podstawie analizy form artystycznych ${ }^{33}$. Po jej przedstawieniu powrócimy do kwestii proweniencji dzieła. Najważniejszym elementem pomocnym w datowaniu niesygnowanych i niepotwierdzonych archiwalnie nowożytnych dzieł rzemiosła artystycznego jest oczywiście ornament, który występował niemal zawsze na tego rodzaju obiektach. Jego analiza pozwala odnieść się do nielicznych, dotyczących mstowskiej sukienki zapisów źródłowych, z których najstarszy pochodzi z 1704 r., zaś kolejne z lat 1744 i 1747. Omawiane dzieło wykonano bliżej tej pierwszej daty. Brak typowej i powszechnej dla 2. połowy XVIII w., a występującej już od czwartej dekady ornamentyki rokokowej pozwala wykluczyć wykonanie sukienki w tym właśnie czasie. W wici roślinnej nie ma bowiem kształtów przypominających lub choćby zapowiadających rocaille ${ }^{34}$. Porównywalne zabytki, a więc sukienki

\footnotetext{
${ }^{31}$ Mariusz KARPOWICZ, „Uwagi o aplikacjach na obrazy i roli sreber w dawnej Rzeczypospolitej”, Rocznik Historii Sztuki, 16:1986, s. 123-158, przedruk: Mariusz KARPOWICZ, Sztuki polskiej drogi dziwne, Bydgoszcz 1994, s. 74-81.

${ }^{32}$ Grażyna JURKOWLANIEC, Epoka nowożytna wobec średniowiecza. Pamiatki przeszłości, cudowne obrazy, dzieła sztuki, Wrocław 2008, s. 187 i nn; o srebrnych sukienkach cudownych obrazów w Europie zob. też Krzysztof CZYŻEWSKI, Marek WALCZAK, „Uwagi o zastosowaniu srebra w sztuce Rzeczypospolitej”, [w:] Fides ars scientia. Studia dedykowane pamięci Księdza Kanonika Augustyna Mednisa, red. Andrzej BETLEJ, Józef SKRABSKI, Tarnów 2008, s. 239-255.

${ }^{33}$ Za szereg uwag i wskazówek uzyskanych w trakcie pisania tej części niniejszego artykułu dziękuję Pani dr Magdalenie Piwockiej i Panu dr. Dariuszowi Nowackiemu z Zamku Królewskiego na Wawelu.

${ }^{34}$ Por. np. sukienki obrazów maryjnych: z poł. XVIII w. w kościele św. Michała Archanioła w Daleszycach, z 1756 r. w kościele par. Św. Trójcy w Koniecpolu: Ornamenta Ecclesiae. Sztuka sakralna diecezji kieleckiej. Katalog wystawy, red. Krzysztof MYŚLIŃSKI, Kielce 2000, nr 251-253, s. 112-113, 132-133.
} 
wykonywane od lat 80 . XVII stulecia do około $1700 \mathrm{r}$. zdobione są z reguły ornamentem akantowym - już dojrzałym i wykształconym - oraz późnym, tzw. suchym akantem.

Motyw wici akantowej był niemal stale obecny w dekoracjach sukienek od 4. ćwierci XVII w. aż po połowę wieku XVIII, różniąc się w tym czasie jedynie redakcją i sposobem formowania szczegółów. Jego występowanie w zdobnictwie tego rodzaju aplikacji łączyć należy przede wszystkim z dążeniem do imitowania wzorów tkanin odzieży, zwłaszcza szat liturgicznych. Powszechną zasadą zdobienia blaszanych sukienek było wytłaczanie motywów floralnych i innych wzorów tekstylnych. Kształtowana w ten sposób, blaszana „odzież” naśladować miała drogie i bogato zdobione wypukłym haftem tkaniny szat liturgicznych. Dobór motywów dyktowała aktualna moda. Szczególnie popularne były różnego rodzaju kwiaty na łodygach, później stopniowo zastępowane przez sam akant ${ }^{35}$. W Mstowie na sukience cudownego obrazu próżno szukać kwiatów. Szaty postaci Matki Boskiej i Dzieciątka Jezus, niemal gładkie, są pofałdowane i pokryte jedynie płytkimi rytami, które układają się w delikatny rysunek o prostych motywach roślinnych, bez bogatszych zdobień rzeźbiarskich. Rezygnacja z motywów kwiatowych - typowych dla tej grupy wyrobów - wiązać mogła się także z rozmiarami obrazka. Elementy takie, w przeciwieństwie do fałd szat oraz perełek, nie byłyby bowiem widoczne z odległości. Należy też pamiętać, że, jak pisze Michał Woźniak, ,inwencja złotników czasem tylko ograniczona była koniecznością imitacji wzoru tekstylnego. Zazwyczaj odchodzili oni od wzoru na tkaninach, modyfikując w duchu współczesnej ornamentyki bądź całkowicie zastępując motywy tekstylne ornamentem nowoczesnym"36.

Na mstowskiej sukience bogatsza dekoracja rzeźbiarska - uzyskana w technice trybowania oraz głębszego rytu - wypełnia całą powierzchnię bordiury oraz płycinę z chrystogramem. Cechą charakterystyczną dzieła jest oryginalne połączenie motywu stylizowanej wici roślinnej i wolut (il. 1-2). Dominują tu esowate oraz c-kształtne, zdobione rytymi kółkami i kropkami woluty, których formy przypominają ornament zwany schweifwerkiem. Był on niezwykle popularny w zdobnictwie w latach 1580-1620, zwłaszcza w złotnictwie, przy czym w tej gałęzi rzemiosła artystycznego zdarzał się w niektórych regionach jeszcze nawet około roku $1700^{37}$. Z kolei szczegóły, takie jak spękania powierzchni oraz większe i mniejsze wybijane wypukło koliste krople, jak również wspomniane już ryte kropki i kółka (będące odpowiednikami chrząstek) należą do repertuaru motywów charakterystycznych dla ornamentu małżowinowo-chrząstkowego. Ten typ zdobień stosowany był do lat 70. XVII w., później stopniowo zanikał i nie pojawiał się na znanych zabytkach sztuki złotniczej ani w ośrodkach pomorskich, ani w Krakowie ${ }^{38}$. Najważniejsze dla datowania omawianego dzieła są jednak drobne akantowe formy

\footnotetext{
${ }^{35}$ WOŹNIAK, op. cit., s. 229-231.

${ }^{36}$ Ibid., s. 233.

37 Günter IRMSCHER, Kleine Kunstgeschichte des europäischen Ornaments seit der frühen Neuzeit (1400-1900), Darmstad 1984, s. 222. O ornamencie wykształconym w grafice ok. 1614 i następnie rozpowszechnionym zwłaszcza w rzemiośle artystycznym: Magdalena ADAMSKA, „Wyroby jubilerskie we wzornikach graficznych XVI i XVII w.”, [w:] Rzadzić i olśniewać. Klejnoty i jubilerstwo w Polsce w XVI i XVII wieku. Eseje, Zamek Królewski w Warszawie Muzeum 2019, s. 211-216.

${ }^{38}$ Dobrym przykładem może tu być sukienka z kościoła w Luborzycy z 1682 r. (dzieło krakowskiego mistrza Jana Młodzianowskiego) zdobiona bogatą dekoracją o motywach floralnych: liści akantu i kwiatów. Tylko w osobno aplikowanych koronach na głowach NMP i Dzieciątka Jezus dostrzec można w wolutowych formach reminiscencje ornamentu małżowinowego. Por. Ryszard MĄCZYŃSKI, „Szaty luborzyckiej Madonny - dzieło złotnika krakowskiego Jana Młodzianowskiego", [w:] id., Blaski złotniczego kunsztu Studia z dziejów rzemiosła artystycznego XVII i XVIII wieku, Torun 2010, s. 36-37, il. 5-8, 11-13, zwłaszcza 7, 10.
} 
liściaste, pojawiające się na zakończeniach wolut i krawędziach wici. W tych miejscach abstrakcyjny w swej genezie ornament manierystyczny (małżowinowo-chrząstkowy) przeobraża się i upodabnia do naturalistycznego (akantowego). Na mstowskim zabytku mamy już do czynienia z wyraźna, późną formą tego ornamentu, o czym świadczy ,usychające”, czy wręcz „wysuszone” listowie, pozwalające zaliczyć dekoracje sukienki do fazy tzw. suchego akantu, który występował na ziemiach Polski od końca XVII stulecia. Jednocześnie wciąż odczuwalny jest tu jeszcze sposób kształtowania i poczucie formy typowe dla ornamentyki XVII-wiecznej, widoczne w kompozycji i szczegółach traktowania wici.

W rozpoznanym dotąd i przebadanym materiale nie znajdujemy bezpośrednich analogii do występującego w omawianym dziele zespołu dekoracji. Wśród zabytków z terenu Rzeczypospolitej wskazać można tylko bardziej odległe podobieństwa, na przykład ornamenty srebrnych antepediów ołtarzowych oraz okładziny niszy cudownej figury Matki Boskiej z kościoła karmelitów w Oborach koło Lipna. Wśród widniejących tam wici akantowych znajdują się c-kształtne wolutowe taśmy. To szczególne połączenie dwóch motywów podobne jest do dekoracji znanej nam z omawianej sukienki, ale w Oborach niektóre woluty zdradzają już cechy ornamentu regencyjnego. Oborska okładzina niszy datowana jest na około 1700 r., natomiast antepedia dopiero na 2. ćwierć XVIII w. ${ }^{39}$, nie wiadomo jednak czy słusznie. W zbiorach Zamku Królewskiego na Wawelu znajduje się datowana na lata 1697-1699 srebrna tacka - wyrób augsburski o podobnym motywie stylizowanej wici akantu o usychających listkach ${ }^{40}$. Dzieło to wydaje się bliższe omawianemu zabytkowi, choć oczywiście przewyższa go pod względem bogactwa motywów i formy artystycznej. Powyższe spostrzeżenia nakazywałyby określić czas wykonania mstowskiej sukienki na ostatnią dekadę XVII w., względnie początek kolejnego stulecia.

Należy podkreślić, że w przypadku omawianego zabytku mamy do czynienia z wyraźnym zapóźnieniem stylowym. Zjawisko takie występowało zwykle w środowiskach prowincjonalnych, prezentujących niejednokrotnie niewysoki poziom umiejętności technicznych. Mstowska sukienka jest tymczasem dziełem wysokiej klasy artystycznej. Aplikacja wykonana została bardzo starannie i umiejętnie przez biegłego w swym rzemiośle złotnika. Współistnienie starszych, zapóźnionych elementów ornamentalnych z nowszymi, aktualnymi stylowo tłumaczyć należałoby więc w tym przypadku spotykaną skądinąd nierzadko w rzemiośle artystycznym zachowawczością. Przykładem takiej koegzystencji motywów dekoracyjnych może być chociażby srebrne antepedium (z 1717 r.) jasnogórskiego ołtarza głównego w kaplicy cudownego obrazu. Obok elementów aktualnych stylowo, a więc kampanul i taśm regencyjnych, znajdują się tam motywy wychodzące z użycia, takie jak wić akantowa, a także całkowicie już anachroniczne kartusze w typie rollwerków i chrząstki ${ }^{41}$.

Sukienka mstowska została niewątpliwie indywidualnie zaprojektowana. Zawarto w niej nawet pewien program ikonograficzny. Dzieło to ma walor oryginalności, wynikający w tym przypadku nie tylko z konieczności dostosowania się do określonego kształtu obrazu. Twórca wykazał się kreatywnością w zakresie kompozycji oraz doboru i ukształtowania form poszczególnych, nieraz bardzo drobnych elementów. Całość odznacza się

\footnotetext{
${ }^{39}$ Katalog zabytków sztuki w Polsce, t. 11: Woj. Bydgoskie, z. 9: Powiat lipnowski, oprac. Ryszard BRYKOWSKI, Izabela GALICKA, Hanna SYGIETYŃSKA, Warszawa 1969, s. 38-19, fig. 190-192.

${ }^{40}$ Zbiory wawelskie. Nabytki 2017-2018. Zamek Królewski na Wawelu, 9 kwietnia - 30 czerwca 2019, red. Jerzy PETRUS, Kraków 2019, s. 29, poz. 29.

${ }^{41}$ Jasnogórski Ottarz Ojczyzny, red. Jan GOLONKA, Częstochowa 1991, il. 88.
} 
dużymi walorami plastyczno-dekoracyjnymi. Oczywiście zastosowane ornamenty to do pewnego stopnia motywy obiegowe, wywodzące się z popularnych wówczas wzorników. Ich „redakcja” jednak oraz oryginalne i umiejętne połączenie świadczy o dużej inwencji artystycznej złotnika. Należy podkreślić, że nie powielał on biernie wzorów. Dobór motywów związany jest tu zapewne z tradycją warsztatu, z którego pochodził. Wskazują na to wspomniany już, nietypowy sposób formowania oraz rzadkie zestawienie i połączenie elementów, wśród których tylko nieliczne i do tego słabo widoczne zdradzają znajomość aktualnych, choć nie najnowszych już wzorów, większość natomiast prezentuje zapóźnienie stylowe, a niektóre - w tym także te dominujące - anachronizm. Świadczyłoby to o powstaniu dzieła w zachowawczym stylowo warsztacie złotniczym, zapewne w ośrodku prowincjonalnym.

Na podstawie analizy formalnej i badań porównawczych wysunąć można szereg wniosków. Zastosowana ornamentyka pozwala stwierdzić, że sukienkę wykonano w końcu XVII w. lub na początku następnego stulecia. W związku z tym przyjąć można również, że najstarszym zachowanym zapisem źródłowym, który odnieść można do omawianego zabytku, jest dokument $\mathrm{z}$ roku $1704^{42}$. Byłaby to zarazem data ante quem dla czasu sporządzenia srebrnej sukienki.

Obecna aplikacja miała jednak, jak sądzę, swoją poprzedniczkę. Trudno bowiem przypuszczać, by z wykonaniem srebrnej sukienki zwlekano aż do początku XVIII w., podczas gdy kult obrazu potężniał od dziesięcioleci, a praktyka ozdabiania tego rodzaju wizerunków aplikacjami stawała się powszechna. Na przykład w kościele opackim w Czerwińsku otoczony kultem obraz Matki Boskiej ozdobiono koronami, a w 1686 r. wyposażono także w srebrną sukienkę pochodzącą z daru ks. Franciszka Józefa Jagodkowicza, kanonika regularnego ${ }^{43}$. Należy nadmienić, że w latach 80 . XVII w. nastąpił rozkwit aplikacji w typie metalowych sukienek. Biorąc pod uwagę stosunkowo niewielkie rozmiary mstowskiego obrazka, sprawienie aplikacji nie wymagało bardzo dużych środków finansowych. Należy też pamiętać, że starszy, czczony w Mstowie obraz maryjny - wizerunek Matki Boskiej Śnieżnej (Różańcowej) miał już srebrne ozdoby dużo wcześniej, bo w roku $1636^{44}$. Niewykluczone, że były to także sukienki. Jeśli zatem chciano rozwijać nowszy kult drugiego obrazu maryjnego, który od 1647 r. znajdował się już w tym samym kościele, to ozdobienie go podobną srebrną sukienką stawało się oczywiste i konieczne.

\section{Próba ustalenia proweniencji}

Rozważając potencjalne miejsca powstania omawianego zabytku, pod uwagę wziąć należy najbliższy ośrodek złotniczy - Częstochowę. O formach tam stosowanych niewiele wiadomo z uwagi na znikomą liczbę zachowanych i pewnych co do proweniencji wyrobów. Dane faktograficzne - zbadane przez Aleksandra Jaśkiewicza ${ }^{45}$ - pozwalają jednak na wyciąnnięcie wniosków, przynosząc ważne informacje na temat aktywności tamtejszych rzemieślników. Ich głównym zadaniem było wykonywanie srebrnych wotów dla

\footnotetext{
${ }^{42}$ Archiwum Archidiecezji Częstochowskiej, sygn. KP 207..., s. 83.

43 Janusz NOWIŃSKI SDB, Czerwińsk, Warszawa 2012.

${ }^{44}$ Ks. Łukasz KORDOWSKI, „Klasztor w Mstowie w świetle akt wizytacji biskupich z 1636 roku” [w:] Mstów..., s. 305.

45 Aleksander JAŚKIEWICZ, ,Złotnictwo wotywne regionu częstochowsko-wieluńskiego. Studium z zakresu sztuki prowincjonalnej i ludowej XVII-XIX wieku”, Rocznik Muzeum Okręowego w Częstochowie, t. 5: Sztuka, z. 1, 1982.
} 
pielgrzymów nawiedzających Jasną Górę, gdzie ten rodzaj darów ofiarnych stał się od XVII w. powszechny i masowy. Najważniejsze w całej Polsce i ściągające rzesze wiernych sanktuarium miało też decydujący wpływ na powstanie w Częstochowie centrum produkcji dewocjonaliów. Co istotne, ośrodek ten zaspokajał potrzeby nie tylko pątników, ale także miejscowego klasztoru paulinów oraz okolicznych konwentów i ośrodków kultu, takich jak na przykład Gidle oraz Mstów ${ }^{46}$. Jak pisze Jaśkiewicz, częstochowscy rzemieślnicy „,nie należeli wcale do artystów reprezentujących główny nurt złotnictwa krajowego. Stanowili [...] odłam zdecydowanie prowincjonalny”, jednak „dobrze sobie radzili z zamówieniami na popularne w XVII i XVIII w. srebrne sukienki do obrazów, blachy ołtarzowe, mniej kosztowne naczynia liturgiczne itp. Tego rodzaju wyroby tworzone w Częstochowie, poza swym dość przeciętnym poziomem wykonania, odznaczały się jeszcze tym, że na ogół nie były znakowane"47. Przykład częstochowskiego wyrobu - analogicznego do omawianego zabytku - jest znany ze źródeł. W 1726 r. miejscowy złotnik Heckenauer podpisał kontrakt na wykonanie sukienki na obraz Matki Boskiej w nowicjacie kościoła św. Barbary w Częstochowie. Wiadomo, że rzemieślnik ten zrobić miał także srebrne lichtarze do kościołów: paulinów w Leśnej i dominikanów w Gidlach ${ }^{48}$. Zaangażowanie przez mstowskich kanoników regularnych miejscowych (?) lub raczej częstochowskich złotników zdają się potwierdzać nielicznie zachowane archiwalia klasztorne. I tak w 1727 r. złotnik Błażej, czynny wówczas w Mstowie, wykonał na zlecenie miejscowego konwentu ,koronki i promienie do obrazu św. Antoniego" oraz kilka innych drobnych prac ${ }^{49}$.

Bardzo dobry poziom wykonania w połączeniu z dość nietypowym repertuarem motywów zdobniczych, w znacznej mierze bardzo zapóźnionych, świadczą o wykonaniu omawianego dzieła w jednym z prowincjonalnych, ale prężnych ośrodków kunsztu złotniczego. W świetle przytoczonych danych można przyjąć założenie, że był to warsztat częstochowski.

\section{Klejnoty na sukience}

Drobnymi, ale cennymi ozdobami sukienki Matki Boskiej Mstowskiej są elementy biżuterii przytwierdzone do wierzchu srebrnej blachy i umocowane od tyłu drutami lub śrubami przechodzącymi przez otwory w blasze. Pochodzą one bez watpienia z XVII stulecia $^{50}$. Niektóre z nich można zidentyfikować z przedmiotami zarejestrowanymi w opisie sukienki z roku $1763^{51}$. Wymieniono tam między innymi „kaszty szmelcowane”, z których kilka ocalało do dziś. Klejnotów i ozdób było wówczas znacznie więcej niż obecnie. Wskazują na to otwory w blasze, dziś puste, a niegdyś bez wątpienia będące miejscami zamocowania precjozów. Większość z tych cennych przedmiotów przepadła w ciągu wieków. Część ozdób jednak przetrwała. Wśród nich uwagę zwracają wzmiankowane „sztuczki” - akcesoria strojów reprezentujące typ biżuterii manierystycznej używany na terenie Europy. W Rzeczypospolitej ozdoby te pozostawały popularne w wieku XVII ${ }^{52}$.

\footnotetext{
46 Ibid., s. 40, 83.

47 Ibid., s. 83.

48 Ibid., s. 91-92.

49 Ibid., s. 93: „łańcuch do trybularza i pałkę do złocistego krzyża”.

${ }^{50} \mathrm{Na}$ temat tego zespołu: Paweł DETTLOFF, „Klejnoty mstowskiego sanktuarium - nieznany zespół biżuterii nowożytnej”, Rzemiosto Artystyczne i Wzornictwo w Polsce, t. 17 (w druku).

${ }^{51}$ ADW, sygn. AAG 59: Akta wizytacji kościoła z 1763 r., s. 1007.

52 Ewa LETKIEWICZ, Klejnoty w Polsce. Czasy ostatnich Jagiellonów $i$ Wazów, Lublin 2006, s. 235; o typach biżuterii: s. 211-254; Dariusz NOWACKI, Magdalena PIWOCKA, Michał GRYCHOWSKI, Klejnoty w dawnej Polsce, Warszawa 2011, s. 117-123.
} 
Z biegiem lat i zmieniającą się modą, gdy zaczęły już wychodzić z użycia, trafiały do kościołów, by tam posłużyć jako ozdoby naczyń i sprzętów liturgicznych, takich jak monstrancje, a zwłaszcza sukienki cudownych obrazów ${ }^{53}$.

\section{Zagadnienie fundacji dzieta}

Nie znamy okoliczności powstania omawianego dzieła. Nie wiemy, czy jest fundacją indywidualną czy zbiorowa, czy też zostało sprawione przez miejscowy konwent zakonny. W tym ostatnim przypadku należałoby wziąć pod uwagę możliwość ufundowania lub sprawienia sukienki przez przełożonego mstowskiego konwentu - prepozyta klasztoru lub kustosza świątyni ${ }^{54}$. Należy też jednak pamiętać, że wiele spośród dzieł sztuki sakralnej znajdujących się w kościołach katedralnych, parafialnych i klasztornych fundowały osoby prywatne, a nie tylko duchowni przełożeni tych świątyń. Zjawisko to było tak powszechne i jest na tyle znane, że nie ma tu potrzeby omawiania go ani mnożenia egzemplifikacji. Wystarczy ograniczyć się zatem do zestawienia przykładów reprezentujących kunszt złotniczy, a mianowicie dwóch barokowych monstrancji zachowanych w skarbcu kościoła klasztornego w Mstowie. Według autorów katalogu zabytków sztuki, jedną z nich ufundować miał w 1708 r. cześnik gostyniński Wojciech Mokrski, drugą zaś w 1732 r. prepozyt Jan Władysław Zakrzowski ${ }^{55}$. O fundacji cześnika informuje inskrypcja na stopie pierwszej monstrancji, natomiast udział finansowy prepozyta, ograniczający się do samego pozłocenia dzieła, określa dość obszerna adnotacja w aktach archiwalnych ${ }^{56}$.

Fundator sprawiający dzieło ze środków prywatnych chciał niekiedy - wobec współczesnych i potomnych - zaakcentować swój akt pobożności, upamiętniając go napisem lub chociażby znakiem, czy herbem. Tylko niektóre sukienki mają takie inskrypcje fundacyjne $^{57}$. Upamiętniają one zwykle osoby indywidualnych darczyńców, towarzyszą im nawet niekiedy ich przedstawienia ${ }^{58}$. O fundatorach wielu ,nieoznakowanych” w ten sposób dzieł dowiedzieć się można już jednak wyłącznie z archiwaliów. Z zachowanych materiałów źródłowych wynika, że prywatni darczyńcy sprawiali niekiedy bardzo kosztowne srebrne ozdoby obrazów. Wymienić tu należy przede wszystkim okazałą oprawę dla cudownej figurki Matki Boskiej Gidelskiej, wykonaną w 1746 r. w całości lub częściowo

\footnotetext{
${ }^{53}$ Ewa SMULIKOWSKA, „Ozdoby obrazu Matki Boskiej Częstochowskiej jako zespół zabytkowy”, Rocznik Historii Sztuki, 10:1974, s. 192, 196; Renata SOBCZAK-JASKULSKA, „Biżuteria w tak zwanej «koronie królowej Jadwigi» z kościoła p. w. Bożego Ciała w Poznaniu”, [w:] Biżuteria w Polsce. Materiały z sesji naukowej zorganizowanej przez Muzeum Okręgowe w Toruniu oraz Toruński Oddział Stowarzyszenia Historyków Sztuki, 20-21 kwietnia 2001, red. Katarzyna KLUCZWAJD, Toruń 2001, s. 57-67. Szerzej na temat tego zjawiska: Danuta SZEWCZYK-PROKURANT, „Z sukien na sukienki... O XVII-wiecznych zabytkach jubilerstwa w polskich zasobach kościelnych”, [w:] Rzemiosło artystyczne $i$ wzornictwo $w$ Polsce, t. 17 (w druku).

${ }^{54}$ ŁATAK, Sanktuarium..., s. 55, 61: autor uważa, że sukienkę sprawił prepozyt Jan Władysław Zakrzowski (17051746). W kontekście ustaleń prezentowanych w niniejszej pracy i wzmianki o sukience z roku 1704 hipotezę tę należy jednak odrzucić.

${ }^{55}$ Katalog zabytków sztuki w Polsce, t. 6: Województwo katowickie, z. 4: Dawny powiat częstochowski, s. 17, fig. 148, 150.

${ }^{56}$ Wiemy, że prepozyt kazał pozłocić monstrancję na własny koszt (45 złotych węgierskich): Archiwum Archidiecezji Częstochowskiej, sygn. KP 207..., s. 91.

${ }^{57}$ Przykładem może tu być fundacja z 1683 r. mieszczan krakowskich - małżeństwa Jana i Zofii Wilkowskich do obrazu Matki Boskiej w kościele św. Jana: Jan SAMEK, „Do zagadnienia sukienek i wotów w sztuce polskiej epoki baroku”, Polska Sztuka Ludowa, 28:1974, z. 4, s. 243-244.

58 Przemysław WOJTACHA, „Metalowe aplikacje w formie szat z przedstawieniami fundatorów”, Roczniki Humanistyczne, 61:2013, nr 4, s. 291-297.
} 
z funduszy Elżbiety Niezabitowskiej ${ }^{59}$, a także srebrne aplikacje na obrazie Imienia Jezus w ołtarzu pod tym samym wezwaniem w kościele dominikanów w Gidlach. Te ostanie, datowane na 1729 r. ${ }^{60}$, sporządzono również na koszt Elżbiety Niezabitowskiej, wymienianej nota bene także wśród darczyńców kościoła klasztornego w Mstowie ${ }^{61}$. O wielu podobnych przedsięwzięciach szlachty i magnaterii, a także mieszczan, nie mamy już dziś jednak żadnych informacji z uwagi na zniszczenie dokumentów i archiwaliów.

Sprawienie obecnej sukienki obrazu Matki Boskiej Mstowskiej, jeśli dokonane zostało na polecenie lub przy udziale samego prepozyta względnie kustosza, to zrealizowano je najprawdopodobniej z funduszy klasztornych lub tylko w części z dochodów prepozyta. Jeszcze bardziej prawdopodobna wydaje się ewentualność wykorzystania starszych wotów, gromadzonych przez dziesięciolecia przy czczonym obrazie. Nie wszystkie przecież musiały paść łupem najeźdźców, a żywy kult, jakim otaczano łaskami słynące obrazy, sprawiał, że stale napływały do nich kolejne wota, ofiary pieniężne i inne dary ${ }^{62}$. Na to, że obecna sukienka obrazu Matki Boskiej Mstowskiej wykonana została z materiału pochodzącego z przetopionych wotów srebrnych ${ }^{63}$, a być może także ze starszej - mniejszej (?) sukienki, wskazywałaby informacja Pruszcza o nieistniejących już dziś ozdobach obrazu ${ }^{64}$.

Zwyczaj wykorzystywania szlachetnych metali pochodzących ze starszych dzieł sztuki w celu sporządzenia nowych przedmiotów i naczyń sakralnych był dość powszechny ${ }^{65}$. Dla naszych rozważań szczególnie pouczający jest kontrakt z 18 kwietnia 1682 r. na wykonanie srebrnej sukienki obrazu Matki Boskiej w kościele par. w Luborzycy. Z treści tej umowy wynika, że materiał (25 grzywien srebra) na zamawiane u złotnika dzieło dostarczyć miał zleceniodawca. Znaczną część kruszcu przekazano wówczas w postaci srebrnej misy oraz dzbana (zapewne kompletu naczyń służących w liturgii Wielkiego Czwartku) ${ }^{66}$. Podobna sytuacja miała miejsce w kościele dominikanów w Sieradzu ${ }^{67}$, gdzie w 1668 r. członkowie miejscowego Bractwa Różańcowego postanowili zamówić srebrną sukienkę na obraz Matki Boskiej w ołtarzu brackim. W tym celu zużyto wcześniej gromadzone kruszce (złoto i srebro) ${ }^{68}$. Z kolei w roku 1726 z trzydziestu dziewięciu ,grzywien srebra konwenckiego" 69 wykonana miała zostać srebrna sukienka dla obrazu Matki Boskiej w kościele św. Barbary w Częstochowie. W nielicznych zachowanych archiwaliach klasztoru mstowskiego odnajdujemy dowody, że tu także stosowano praktykę wykorzystywania zgromadzonych wotów. I tak w październiku 1730 r. miejscowy prałat (prepozyt) Jan Władysław Zakrzowski oddał do zakrystii ,parę lichtarzy srebrnych z ofiarnego srebra

\footnotetext{
${ }^{59}$ DETTLOFF, Domus Aurea..., s. 154-155.

${ }^{60}$ Ibid., s. 216, 364-365.

${ }^{61}$ Archiwum Archidiecezji Częstochowskiej, sygn. KP 207..., s. 92.

${ }^{62}$ Szereg z nich wymienia księga wydatków zakrystii: Archiwum Archidiecezji Częstochowskiej, sygn. KP 207..., s. 92.

${ }^{63}$ Mogła to być aplikacja niepokrywająca całego wizerunku, tak jak to jest obecnie, ale jedynie jego fragmenty, np. same szaty postaci.

${ }^{64}$ PRUSZCZ, op. cit., s. 38.

${ }^{65}$ Jednym z licznych przykładów jest relikwiarz św. Stanisława w katedrze wawelskiej, który sporządzono częściowo ze starego, pochodzącego z XIII w. relikwiarza z fundacji księżnej Kingi: Michał ROŻEK, Katedra wawelska w XVII wieku, Kraków 1980, s. 82. Przywołać można tu także srebrne kandelabry ołtarza głównego kolegiaty w Sandomierzu (1751), dla których wykonania przetopiono dotychczasowe, mniejsze kandelabry: Agata DWORZAK, Fabrica ecclesiae sandomiriensis. Dzieje modernizacji wnętrza kolegiaty sandomierskiej w XVIII wieku w świetle źródet archiwalnych, Kraków 2016, s. 75.

${ }^{66}$ MĄCZYŃSKI, op. cit., s. 44.

${ }^{67}$ Paweł MIGASIEWICZ, Kościół podominikański w Sieradzu, Warszawa-Sieradz 2003, s. 105.

${ }^{68}$ Ibid., s. 105

${ }^{69}$ JAŚKIEWICZ, op. cit., s. 91-92.
} 
zrobionych"70. Ten sam prałat był inicjatorem wykonania nowej monstrancji. Wykonano ją z 25 grzywien ,srebra kościelnego i kilkunastu sztuczek rubinowych i perłowych” oraz „korali także kościelnych”71, a zatem biżuterii wcześniej ofiarowanej przez wiernych.

\section{Symbolika i treści}

Zespół zdobień na sukience obrazu Matki Boskiej Mstowskiej, oprócz niewątpliwych wartości dekoracyjnych, posiada także istotny walor treściowy. Ikonografia wizerunku odnosi się oczywiście do jego tematu. Najsilniejszym akcentem plastycznym sukienki jest przedstawienie w górnej części bordiury - wyobrażenie Ducha Świętego pod postacią gołębicy, umieszczonej na tle palmetowej muszli z parą aniołów po bokach (il. 1, 3). Przedstawienie to akcentuje wątek wcielenia Syna Bożego, zapowiedziany w scenie Zwiastowania. W ikonografii tego wydarzenia często pojawia się gołębica Ducha Świętego ${ }^{72}$. $\mathrm{Na}$ omawianym zabytku postać trzeciej osoby Trójcy Świętej umieszczono na tle muszli, która w symbolice chrześcijańskiej oznacza czystość i niepokalaność Maryi Panny ${ }^{73}$. Muszla jest tu zatem nie tylko elementem dekoracyjnym, ale także symbolicznym znakiem wybraństwa Maryi Dziewicy oraz niepokalanego poczęcia Chrystusa w jej łonie. Postacie anielskie adorują Ducha Świętego, ale swoim usytuowaniem przypominają pojawiające się często na wizerunkach Matki Bożej pary aniołów, adorujące Królową Nieba lub podtrzymujące jej koronę (il. 1, 3-4). Najważniejszymi ideowo elementami sukienki są oczywiście repusowane korony (pierwotne pozostają obecnie niewidoczne, bo zasłonięte przez korony nałożone w roku 2000), które wraz z promienistymi nimbami wokół głowy Najświętszej Panny podkreślać miały jej godność Królowej Nieba (il. 1, 6).

Jak wiadomo, zwyczaj ozdabiania koronami czczonych wizerunków maryjnych początkowo nie musiał wiązać się z oficjalnym aktem koronacji obrazu przez hierarchów kościelnych. Dobrym tego przykładem były ozdoby cudownego obrazu jasnogórskiego, nakładane na wizerunek już od XVI w., a zatem długo przed oficjalną koronacją Matki Boskiej Częstochowskiej koronami papieskimi w roku $1717^{74}$. Korony nakładano także na inne, mniej znane i otoczone tylko lokalnym kultem wizerunki maryjne ${ }^{75}$. Wytłoczone na srebrnej sukience mstowskiego obrazu korony mają bardzo skromną formę. Nad niską obręczą znajdują się niewielkie sterczyny, a nad nimi wysoki, kołpakowaty czepiec. Kształt tych koron nie wykazuje zatem bliższych związków z formą insygniów monarszych nakładanych na obraz Matki Boskiej Częstochowskiej. Należy jednak pamiętać, że, choć reprodukcje jasnogórskiego obrazu oddawały jego aktualny wygląd wraz z wszystkimi ozdobami, pewne szczegóły w trakcie tworzenia kolejnych graficznych redakcji wizerunku ulegały jednak uproszczeniu ${ }^{76}$. $\mathrm{Z}$ archiwalnego opisu dowiadujemy się, że w $1763 \mathrm{r}$. korony sukienki Matki Boskiej Mstowskiej pokryte były gęsto biżuterią z kamieniami

\footnotetext{
${ }^{70}$ Archiwum Archidiecezji Częstochowskiej, sygn. KP 207..., s. 91.

${ }^{71}$ Ibid.

${ }^{72}$ Gertrud SCHILLER, Ikonographie der Christlichen Kunst, B. 1, Gütersloh 1966, s. 44, 53 i nn, fig. 96-124.

${ }^{73}$ Władysław KOPALIŃSKI, Słownik symboli, Warszawa 1991, s. 239-241.

74 SMULIKOWSKA, op. cit., s. 55-88; Jerzy ŻMUDZIŃSKI, „Czy Anna Jagiellonka ufundowała koronę do obrazu Matki Boskiej Częstochowskiej?”, [w:] Dawna i nowsza biżuteria w Polsce, t. 8, Toruń 2008, s. 82-83.

${ }^{75}$ Dobrym przykładem może tu być korona na obrazie Najświętszej Marii Panny w bocznym ołtarzu przytęczowym w krakowskim kościele Bożego Ciała. Aplikacja ta, wykonana z metalu i pozłocona, sprawiona została (zapewne ufundowana) przez Wojciecha Zawadę w roku 1644, o czym świadczy napis na odwrociu, odkryty i odczytany po raz pierwszy przez autora (17 X 2018) w trakcie komisji konserwatorskiej.

${ }^{76}$ SMULIKOWSKA, op. cit., s. 75-76.
} 


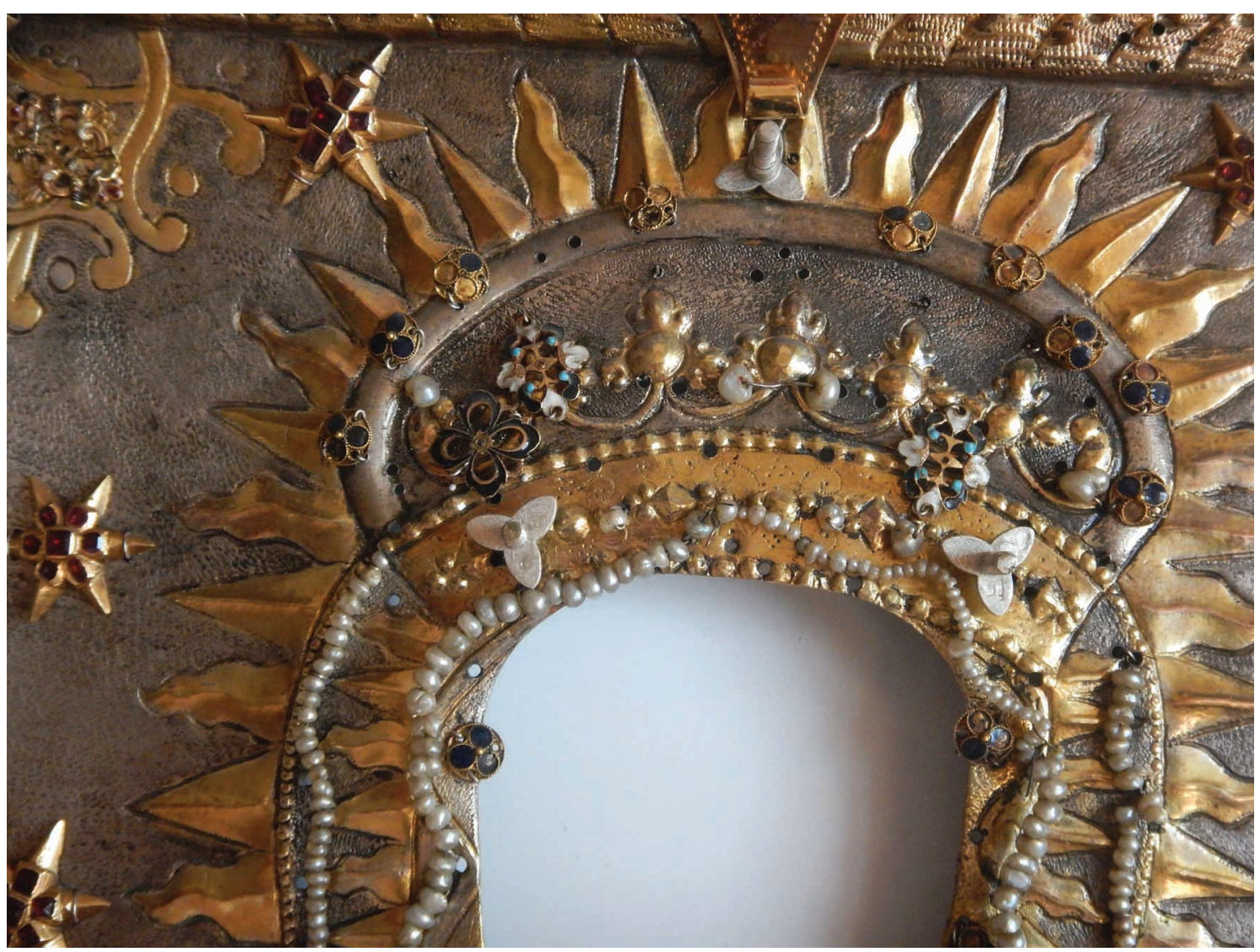

6. Fragment srebrnej sukienki - promienie i korona Matki Boskiej Mstowskiej. Fot. P. Dettloff

szlachetnymi. Wytłoczone korony były zatem w części tylko tłem dla pokrywających je klejnotów, które niepomiernie wzbogacały insygnia i tworzyły z nich bogatsze, ,prawdziwe" korony, migocące od złota, pereł i barwnych kamieni szlachetnych.

Wokół głowy Najświętszej Marii Panny umieszczona jest promienista aureola (il. 1, 6) przypominająca swym układem motyw solarnej mandorli ${ }^{77}$, który, podobnie jak w przypadku glorii promienistych monstrancji barokowych, ma wymowę symboliczną. Nawiązuje do wizji Niewiasty „obleczonej w słońce”, opisanej przez św. Jana Ewangelistę (Ap 12, 1). Słońce, którego promienie otaczają głowę Marii, ma w chrześcijańskiej symbolice bogate odniesienia i długą tradycję ${ }^{78}$. Zgodnie ze słowami Pieśni nad pieśniami Maryja jest ,jaśniejąca jak słońce" (Pnp 6, 10). Promienie wokół niej symbolizować mogą blask doskonałości i świętości, która jaśnieje wśród wszystkich stworzeń rozumnych - ludzi i aniołów, a blask ten słusznie przyrównywany bywa do blasku słońca ${ }^{79}$. Symbolika solarna obejmuje także (u św. Bernarda z Clairvaux) odniesienia do miłosierdzia Maryi, ogarniającego swym światłem wszystkich ludzi - dobrych i złych ${ }^{80}$. Od XVII stulecia kompozycje promieniste pojawiały się powszechnie wśród wyrobów złotnictwa o przeznaczeniu sakralnym, stając się

\footnotetext{
${ }^{77}$ Na taką kwalifikację typologiczną i zarazem ikonograficzną wskazują podobne przedstawienia, w których promienista mandorla otacza zazwyczaj całą postać Niewiasty Apokaliptycznej.

${ }^{78}$ Jerzy MIZIOŁEK, Sol Verus. Studia nad ikonografia Chrystusa w sztuce pierwszego tysiaclecia, Wrocław-Warszawa-Kraków 1991, s. 85 i nn.

${ }^{79}$ Cyt. za: GOLONKA, op. cit., s. 248.

${ }^{80}$ Louis RÉAU, Iconographie de l'art Chrétien, t. 2: Iconographie de la Bible, 2: Nouveau Testament, Paris 1957, s. 708 i nn.
} 


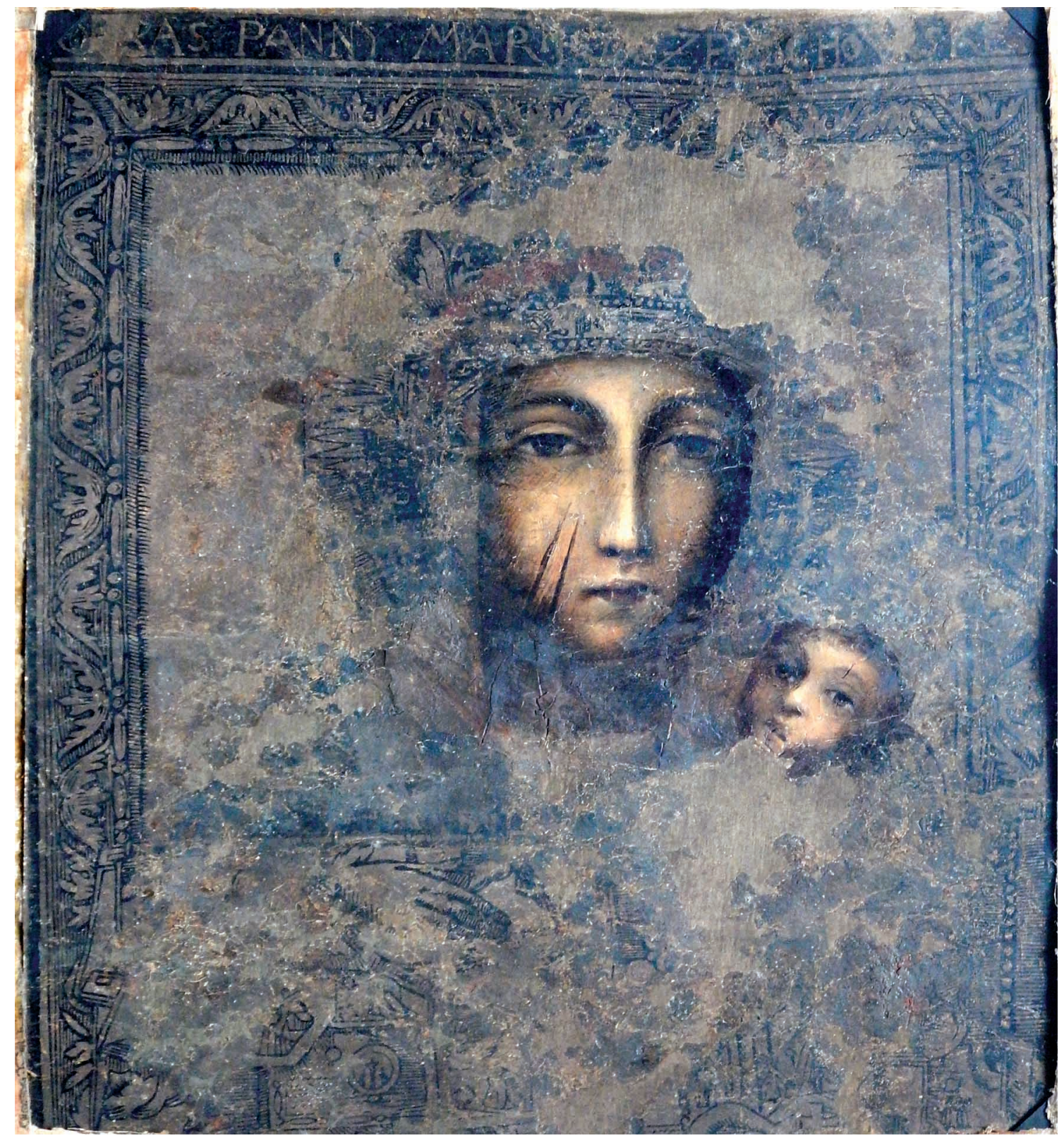

7. Wizerunek Matki Boskiej Mstowskiej bez srebrnej sukienki. Stan z 2018 r. Fot. P. Dettloff 
nieodłącznym elementem ikonograficznym monstrancji. Symbolika i forma solarnej mandorli na sukience Matki Boskiej Mstowskiej wskazuje na typowe dla czasów baroku powiązanie kultu Najświętszego Sakramentu z kultem Najświętszej Maryi Panny ${ }^{81}$. Charakterystyczną cechą aureoli jest alternacja kształtów, w ramach której proste, szpiczaste promienie umieszczone są przemiennie z promieniami płomienistymi. Taką kompozycję spotykamy już we wczesnych przykładach monstrancji promienistych w Polsce, pochodzących z lat 40. wieku XVII ${ }^{82}$. Później było to już rozwiązanie obiegowe, a jednym z jego wielu przykładów może być choćby wspomniana już monstrancja z 1708 r. w kościele kanoników regularnych w Mstowie.

U dołu ,srebrnego obrazu” widnieje trigram Chrystusa - IHS. Umieszczony w eksponowanym miejscu, jest silnym akcentem kompozycyjnym i ideowym zarazem (il. 1, 5). Podkreśla osobę Syna Bożego. Chrystogram znajduje się także w centralnym miejscu nastawy ołtarza Matki Boskiej Częstochowskiej na Jasnej Górze ${ }^{83}$. W Mstowie, podobnie jak tam, chrystogram ma zatem znaczenie teologiczne, a konkretnie chrystologiczne. Warto przy tym zwrócić uwagę, że omawianego trigramu nie ma na oryginalnym, cudownym wizerunku pierwotnej odbitce graficznej. W jego miejscu widnieją tam słabo czytelne ślady kwater ze scenami figuralnymi (il. $1,5,7)$. Ich powtórzenie na blasze byłoby niewidoczne ze względu na niewielkie rozmiary, dlatego zdecydowano się zapewne na zastąpienie tej części dużym i wyraźnym motywem chrystogramu. Co znamienne, widnieje on także na wtórnym, nałożonym na pierwotny obraz przedstawieniu, które do czasu konserwacji w 1939 r. pokrywało oryginał, przejmując jego rolę (il. 8). Jak można przypuszczać, zniszczenie oryginału spowodowało konieczność wykonania substytutu. W schematycznym odwzorowaniu obrazu nie posłużono się jednak autentykiem (prawdopodobnie z uwagi na jego nieczytelność), lecz widoczną dla wszystkich sukienką ${ }^{84}$. Wskazuje na to nie tylko obecność chrystogramu, ale także szczegóły koron i twarzy, odmienne od znanych do tego czasu graficznych wyobrażeń obrazu jasnogórskiego.

Ryciny wyobrażające cudowny wizerunek Matki Boskiej Częstochowskiej posłużyły natomiast najprawdopodobniej w opracowaniu podstawowych elementów i symboli obecnych na srebrnej sukience mstowskiej. Gołębica Ducha Świętego w górnej części przedstawienia umieszczona jest na przykład na rycinie Theodora Galle z ok. $1610 \mathrm{r}^{85}$, z kolei muszla widnieje na miedziorytniczym przedstawieniu Wolfganga Kiliana z ok. 1640 r., popularyzującym wizerunek jasnogórski w Austrii ${ }^{86}$. Szczególną uwagę zwraca jednak anonimowa odbitka graficzna datowana na początek XVIII stulecia (i1. 9) ${ }^{87}$. Obraz Bogarodzicy otacza tu szeroka bordiura o motywach roślinnych z kwiatami, promienista gloria okala tylko głowę Maryi (co jest dość rzadkie), a u dołu widnieje chrystogram w koronie cierniowej, który podtrzymywany i adorowany jest przez parę aniołów (ten motyw pojawia się także w innych przedstawieniach tego typu). Rycina ta wydaje się też bliska autentycznemu (pierwotnemu) wizerunkowi Matki Boskiej Mstowskiej poprzez obecność nie

\footnotetext{
${ }^{81}$ GOLONKA, op. cit., s. 248.

${ }^{82}$ Michał WOŹNIAK, „Wpływy augsburskie w złotnictwie gdańskim XVII-XVIII stulecia”, Biuletyn Historii Sztuki, 47:1985, z. 1-2, s. 110-121, il. 14-18.

${ }^{83}$ GOLONKA, op. cit., s. 248; obecny chrystogram jest rekonstrukcją w oparciu o XVII-wieczną odbitkę graficzną: Jasnogórski Ottarz...., il. 91.

${ }^{84}$ Pominięto przy tym promienistą aureolę i nimb wokół głowy Maryi.

${ }^{85}$ Ks. Ryszard KNAPIŃSKI, „Nieznane grafiki z wizerunkiem Matki Bożej Częstochowskiej”, [w:] Zwycięstwo przychodzi przez Maryje, red. Zachariasz S. JABŁONSSKI OSPPE, Teofil SIUDY, Częstochowa 2006, s. 91, ryc. 14.

${ }^{86}$ Ibid., s. 107-108, ryc. 23-24.

${ }^{87}$ Ibid., s. 110, 115-116, ryc. 25.
} 


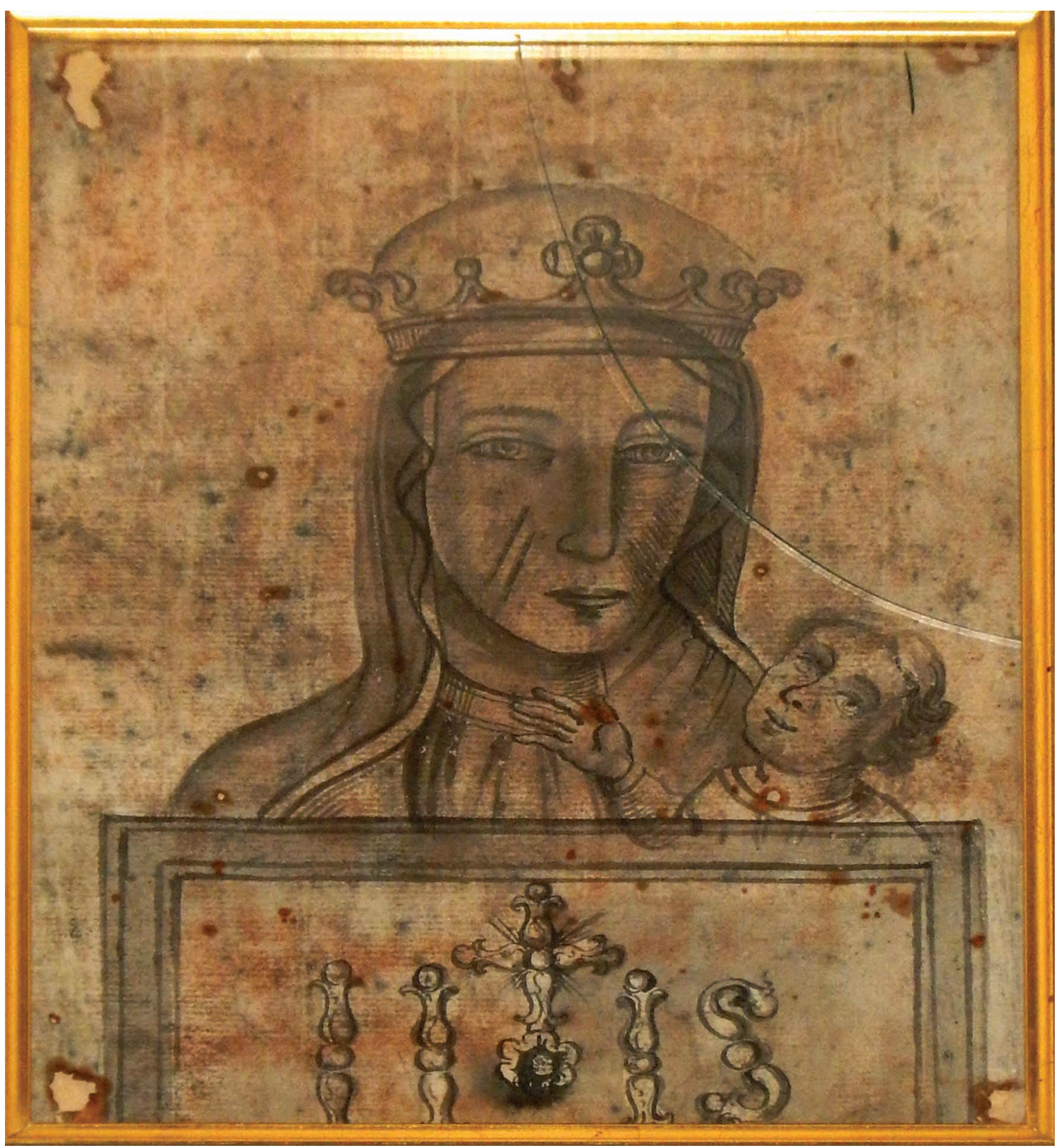

8. Graficzne wyobrażenie Matki Bożej Mstowskiej, niegdyś zakrywajace oryginat wizerunku. Stan z 2018 r. Fot. P. Dettloff 


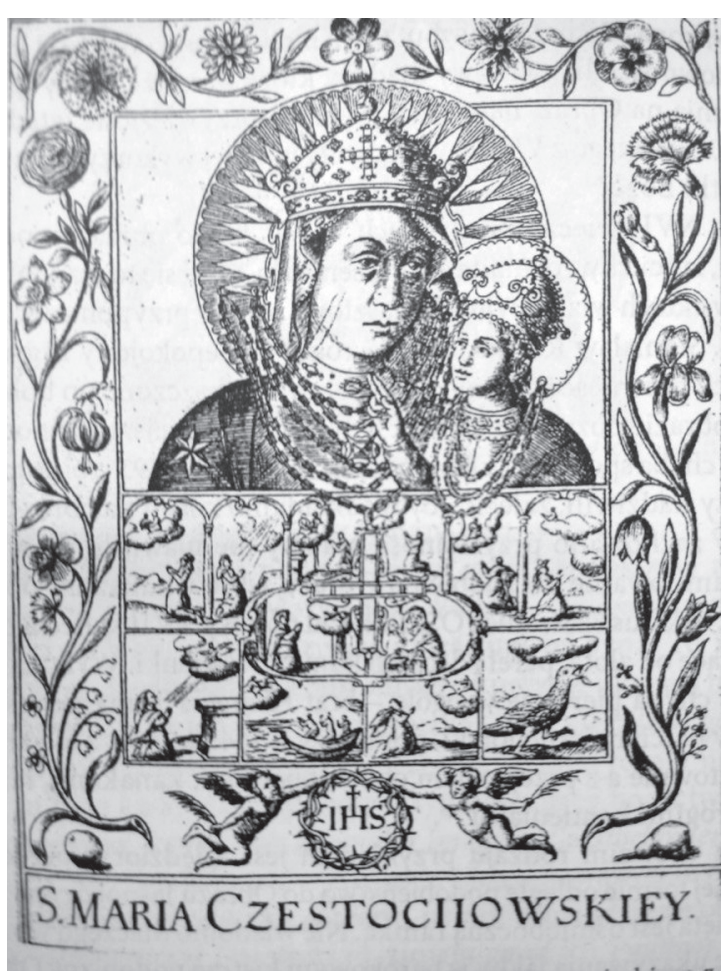

9. Grafika z pocz. XVIII w. (?) z wyobrażeniem Matki Boskiej Częstochowskiej. Repr.wg Ks. R. Knapiński, Nieznane grafiki..., il. 25

tylko dekoracyjnej bordiury, ale zwłaszcza scen figuralnych w dolnej części przedstawienia oraz kolistego nimbu i promieni wokół głowy Maryi. Sam motyw bordiury o floralnym wzorze pozostaje właściwie jedynym wyraźnym elementem zdobniczym łączącym oryginał wizerunku i jego srebrną okładzinę (il. 1,7). Do dziś jest on dobrze zachowany na pierwotnym obrazie. Składa się wyłącznie ze stylizowanych listków przypominających akant. Zastosowanie wici akantowej (bez kwiatów) na bordiurze srebrnej sukienki mogło mieć zatem znaczenie ikonograficzne, jako nawiązanie do pierwowzoru. Dokonano tego oczywiście w swobodnej redakcji, dostosowanej do aktualnej ornamentyki.

Przyjmuje się, że w przypadku zniszczenia otaczanego kultem i ozdobionego metalowa aplikacją malowidła było ono odnawiane lub wykonywane na nowo w dostosowaniu do formy istniejącej już sukienki ${ }^{88}$. Tak stało się w Mstowie. Kwestią otwartą pozostaje kolejność wykonania wtórnego obrazu graficznego oraz srebrnej aplikacji. Niewykluczone, że powstały one równocześnie, a nałożenie obecnej sukienki połączono z włożeniem nowej karty z wyobrażeniem cudownego wizerunku. Nie ulega natomiast wątpliwości wzajemny związek odbitki i blachy. W kontekście tych spostrzeżeń tym bardziej wyrazista okazuje się znacząca, czy wręcz kluczowa rola srebrnej sukienki w ukonstytuowaniu się cech wizualnych cudownego wizerunku Matki Boskiej Mstowskiej. Co najmniej od początku XVIII w., a prawdopodobnie także już wcześniej sukienka zakrywała oryginalny, cudowny obraz Bogarodzicy, powiększając go optycznie i stając się w istocie nim samym. Dobrze widoczna dla wiernych przejęła rolę ukrytego pod nim właściwego wizerunku. Co więcej, prawdziwy wygląd tego ostatniego był niemal do naszych czasów praktycznie nieznany ${ }^{89}$.

\footnotetext{
${ }^{88}$ Tadeusz CHRZANOWSKI, Marian KORNECKI, „Wota srebrne. Z badań nad sztuką sarmatyzmu w Polsce”, Biuletyn Historii Sztuki, 32:1970, z. 2, s. 214.

${ }^{89}$ Dowodzi tego dobitnie fakt długotrwałego zakrycia oryginalnej XVII-wiecznej ryciny przez wtórny obrazek o innym wyglądzie, widoczny zresztą tylko w obrębie twarzy i to bardzo słabo. Warto też dodać, że obecnie (w 2019 r.) na czas konserwacji ołtarza cudowny wizerunek zastapiono kopią nie tylko samego obrazu, ale i srebrnej sukienki. Te nowe artefakty, umieszczone na ołtarzu głównym, z daleka trudno było odróżnić od ich pierwowzorów.
} 
Zdaniem niektórych badaczy aplikacje i sukienki nakładane na obrazy stawały się swoistą konkurencją wobec oryginału, zatracając z nim związek artystyczno-formalny. Wykonywane jako trawestacje obrazu w innej technice i odmiennym materiale, były dziełami wtórnymi, a zarazem autonomicznymi wobec samych malowide ${ }^{90}$. W Mstowie mamy do czynienia z podobną sytuacją. Rozbieżność między oryginałem przedstawienia, a jego wyobrażeniem na zakrywającej blasze jest znaczna. W tym przypadku jednak dzieło sakralne - przykryte przez stulecia sukienką - w świadomości odbiorców funkcjonowało w takiej właśnie postaci, czyniąc „,srebrny obraz” bliższym i bardziej rozpoznawalnym niż pierwotny malarski wizerunek.

\section{Podsumowanie}

Srebrna aplikacja w typie tzw. sukienki pokrywająca obraz Matki Boskiej Mstowskiej jest interesującym i cennym dziełem sztuki złotniczej, a zarazem ważnym świadectwem materialnym kultu, jakim cieszył się w czasach baroku ten cudowny wizerunek. Zabytek mstowski wpisuje się w tradycję zdobienia obrazów sakralnych metalowymi aplikacjami. Jest jedną z bardzo licznych i występujących masowo na terenie Rzeczypospolitej oraz innych katolickich krajów Europy sukienek nakładanych na tego rodzaju obrazy. Prezentuje jednak mniej typową odmianę. Zakrywająca niemal w całości rycinę z wyobrażeniem Bogarodzicy i znacznie wykraczająca poza jej niewielkie rozmiary, srebrna blacha z plastycznym przedstawieniem postaci przejęła w praktyce rolę oryginału. Stała się bowiem jego wizualnym przetworzeniem i niejako ,nowym obrazem” (il. 1, 7). W tej właśnie postaci widoczna jest do dziś dla wiernych. Interesująca pozostaje także zależność motywów przedstawionych na sukience od graficznych wyobrażeń popularyzujących cudowny obraz Matki Boskiej Częstochowskiej. Okoliczności oraz dokładna data powstania i fundacji dzieła pozostają nieznane. Na podstawie przedstawionej powyżej analizy możemy jednak zakładać, że sukienkę wykonano w ostatnim dziesięcioleciu wieku XVII lub na początku następnego stulecia, zapewne przed rokiem 1704. Zwraca ona uwagę oryginalnie i umiejętnie zaprojektowaną kompozycją oraz ,kompilowaną” dekoracją ornamentalna. Prezentuje także dobry poziom wykonania. Choć pod względem stylowym pozostaje dość zapóźniona, jest jednak bardzo cennym dziełem rzemiosła artystycznego - tworem anonimowego, zapewne częstochowskiego warsztatu, dowodzącym jego technicznych $i$ artystycznych możliwości. Ważnym zespołem, integralnie związanym z omawianym zabytkiem są XVII-wieczne elementy biżuterii zdobiące srebrną blachę sukienki.

${ }^{90}$ JURKOWLANIEC, op. cit., s. 187-190; WOJTACHA, op. cit., s. 292. 


\section{'Silver Painting' from the Church of the Canons Regular in Mstów}

The silver robe covering the miraculous painting of Our Lady of Mstow in the church of the Canons Regular in Mstów (at present currently Wancerzów) near Częstochowa is discussed. The oldest written record referring to this artifact dates back to 1704, defining it as a 'silver painting'. Actually, the silver appliqué design on the miraculous effigy covers almost the whole of its surface (except for the faces), while the shape of the cover resembles the representation underneath. The robe was made of silver, partially gilded embossed sheet, engraved in parts. The upper part of figural elements are almost solid realistically rendered, made as a cast. An interesting and precious piece of goldsmithery, encompassed within the tradition of adorning miraculous images with metal applications, it ranks among the robes put upon sacral pictures so numerous in the Polish-Lithuanian Commonwealth, representing, however, its less typical variety. Covering the whole of the painting showing Our Lady, it is actually bigger $(48 \times 38 \mathrm{~cm})$ than the small picture itself $(25 \times 30$ $\mathrm{cm})$. The silver sheet, namely the application with a full-bodied presentation of the figure, has practically taken over the role of the original. In this way, it has become its visual transformation and a 'new picture'. This is the version the faithful have seen until today. Furthermore, the dependence of the depictions on the robe on the print popularizing the miraculous effigy of Our Lady of Częstochowa is interesting. Neither the circumstances nor the exact date of the piece's foundation are known. However, based on the above analysis, it can be assumed that the dress was executed in the last decade of the $17^{\text {th }}$ century or in the early $18^{\text {th }}$ century, most likely before 1704 . What strikes in the work is a genuine design composition and 'compiled' ornamental decoration, as well as high quality of craftsmanship. Among the applied ornaments, acanthus and auricular motifs, the latter resembling schweifwerk ornament, can be found. Although stylistically retarded, the Mstów robe remains a precious work of artistic craftsmanship; an anonymous piece produced possibly by a Częstochowa workshop; it demonstrated its high technical and artistic capacity. An important set, integrally connected with the discussed artifact, can be seen in the $17^{\text {th }}$-century pieces of jewellery adorning the silver sheet of the robe. 
